\title{
New species of Muricidae Rafinesque, 1815 (Mollusca: Gastropoda) from the Western Indian Ocean
}

\author{
Roland HOUART \\ Research associate, Institut royal des Sciences naturelles de Belgique, \\ rue Vautier, 29, B-1000 Bruxelles (Belgium) \\ roland.houart@skynet.be \\ Virginie HÉROS \\ Institut de Systématique, Évolution, Biodiversité, \\ UMR 7205 CNRS, MNHN, UPMC, EPHE, \\ Muséum national d'Histoire naturelle, Sorbonne Universités, \\ case postale 50, 57 rue Cuvier, 75005 Paris (France) \\ malaco@mnhn.fr
}

Published on 25 September 2015

KEY WORDS

Mollusca,

Gastropoda,

Muricidae

Western Indian Ocean,

new species.

MOTS CLÉS

Mollusques,

Gastéropodes, Muricidae,

Océan Indien occidental espèces nouvelles.
urn:Isid:zoobank org:pub:EDB0C7A2-7B5E-4E39-91CE-B823BB38ACA0

Houart R. \& Héros V. 2015. - New species of Muricidae Rafinesque, 1815 (Mollusca: Gastropoda) from the Western Indian Ocean. Zoosystema 37 (3): 481-503. http://dx.doi.org/10.5252/z2015n3a4

\section{ABSTRACT}

Ten new species of Muricidae Rafinesque, 1815 are described from material collected during expeditions in Madagascar. Five species are described from the Extreme South: Vokesimurex rectaspira n. sp., Timbellus goniodes n. sp., Flexopteron akainakares n. sp., Murexsul mananteninaensis n. sp. and Typhinellus constrictus $\mathrm{n}$. sp.; four from the Northwest: Vokesimurex aliquantulus n. sp., Timbellus pannuceus n. sp., Typhinellus laminatus n. sp. and Siphonochelus (Siphonochelus) aethomorpha n. sp.; and a single species, Bouchetia wareni n. sp., is described from both the Extreme South and the Northwest and is also reported from Mayotte. Similar species from Madagascar, Mozambique and from other regions of the Indo-West Pacific are compared. The radulae of Vokesimurex rectaspira n. sp., Flexopteron akainakares n. sp., Flexopteron primanova (Houart, 1985) and Bouchetia vaubanensis Houart, 1986 are illustrated.

\section{RÉSUMÉ}

Nouvelles espèces de Muricidae Rafinesque, 1815 (Mollusca: Gastropoda) de l'océan Indien occidental. Dix nouvelles espèces de Muricidae Rafinesque, 1815 sont décrites à partir de matériel récolté au cours d'expéditions menées à Madagascar. Cinq espèces sont décrites de l'extrême-sud : Vokesimurex rectaspira n. sp., Timbellus goniodes n. sp., Flexopteron akainakares n. sp., Murexsul mananteninaensis n. sp. et Typhinellus constrictus n. sp.; quatre sont décrites du nord-ouest de Madagascar: Vokesimurex aliquantulus n. sp., Timbellus pannuceus n. sp., Typhinellus laminatus n. sp. et Siphonochelus (Siphonochelus) aethomorpha n. sp.; et une seule espèce, Bouchetia wareni n. sp., est décrite à la fois de l'extrême-sud et du nord-ouest et est aussi signalée à Mayotte. Des espèces similaires de Madagascar, du Mozambique et d'autres régions de l'Indo-Ouest Pacifique, sont comparées. Les radulas de Vokesimurex rectaspira n. sp., Flexopteron akainakares n. sp., Flexopteron primanova (Houart, 1985) et de Bouchetia vaubanensis Houart, 1986 sont illustrées. 


\section{INTRODUCTION}

Our knowledge of the marine biodiversity of Madagascar is to a very large extent based on research carried in the regions of Nosy-Be and Tulear (Toliara), both located in the "Western and Northern Madagascar" marine ecoregion (Spalding et al. 2007) and characterized by extensive coral reefs ecosystems. By contrast, the "Deep South" of Madagascar is an oceanic region of exposed promontories, open bays and extensive algal belts. The lack of infrastructures has arguably made it the least visited and least known coastline in the country. The marine hydroclimate is characterized by a coastal upwelling with cold surface water and high concentrations of chlorophyll- $a$ (Lutjeharms \& Machu 2000), with winter sea surface temperatures as low as $21.5^{\circ} \mathrm{C}$, vs $24-25^{\circ} \mathrm{C}$ or more elsewhere around Madagascar (Piton \& Laroche 1993). From the late 1990's, new species of molluscs started to be discovered on the coastline of the Anosy and Androy regions, first serendipitously as a by-product of the local lobster fishery (e.g., Bouchet 1999), and later specifically attracting shell collectors and amateur taxonomists (e.g., Bozzetti 2001, 2006, 2011). These scattered findings and the unique oceanographic background, together suggested that the "Deep South" of Madagascar had a potential for more discoveries, and this was what motivated a large-scale exploring expedition by the Muséum national d'Histoire naturelle (Paris, France) that sampled the benthos of the region in April-June 2010. The name of the Expedition, ATIMO VATAE, means "Deep South" in the Antandroy language. For baseline information on the project, see http:// laplaneterevisitee.org/en/87/accueil. Beside ATIMO VATAE, the MIRIKY expedition, using a local trawler, surveyed the benthic fauna off NW Madagascar between Cap d'Ambre and Cap Saint-André.

The results of the ATIMO VATAE and MIRIKY expeditions are now starting to be published and confirm the "Deep South" of Madagascar as a site of high endemism, with many new species. For instance, 39 of the 70 species of Cerithiopsidae $\mathrm{H}$. Adams \& A. Adams, 1854, and six of the eight species of Calliostomatidae Thiele, 1924, collected were new to science (Cecalupo \& Perugia 2014; Vilvens 2014). With over 120 species, the family Muricidae Rafinesque, 1815 is well represented in the expeditions material. Houart \& Héros (2013) described six new species, and ten more are described in the present paper - five from the "Deep South" and five from the North-West, with no overlap between the two regions. A forthcoming regional monograph will cover the family in its entirety, presenting new regional records, revising the nominal species with a Madagascar Deep South type locality, including molecular barcodes for many species, and discussing endemism (in collaboration with Marco Oliverio University La Spienza, Roma).

\section{MATERIAL AND METHODS}

The material studied in the present paper originates mainly from two recent, ATIMO VATAE and MIRIKY expeditions.
The ATIMO VATAE expedition was organized by the Muséum national d'Histoire naturelle (MNHN, Paris), the Institut d'Halieutique et des Sciences marines, University of Toliara (IH.SM), and the Wildlife Conservation Society (WCS) Madagascar Programme to explore the coastal marine fauna and flora in a cold oceanic region of rugged promontories, open bays and extensive algal belts. The ATIMO VATAE cruise collected 118 species of Muricidae (excluding Coralliophilinae Chenu, 1858) during April-June 2010. Tissue samples were clipped from many of them for DNA sequencing.

The MIRIKY expedition formed part of a cluster of Mozambique-Madagascar expeditions funded by the Total Foundation, the Prince Albert II of Monaco Foundation, and the Stavros Niarchos Foundation, and conducted by MNHN and Pro-Natura International (PNI).

The Madagascan trawler Miriky explored the Northwest of Madagascar, between Cap d'Ambre, in the North, and Cap Saint André, in the West. In 20 days during June and July 2009, the MIRIKY made 140 dredgings and trawlings. The objective of this expedition was to explore a less studied zone, the North of the Mozambique Channel, near Madagascar, in depths between 100 and $1200 \mathrm{~m}$.

Other material described was collected by A. Crosnier, off NW Madagascar, in 1972-73, aboard R.V. Vauban and during the BENTHEDI expedition in 1977, aboard R.V. Suroit (northern Mozambique Channel).

Empty shells reported here were collected in depths from 21 to $600 \mathrm{~m}$, live collected specimens from 13 to $492 \mathrm{~m}$.

\section{METHODS FOR MORPHOLOGICAL TAXONOMY}

The characters used here to describe shell morphology are the general aspect of the shell, shape and size, colour, shape of the spire and number of protoconch and teleoconch whorls, features of the protoconch, shape of the teleoconch whorls and features of the suture and of the subsutural band, axial and spiral sculpture, aperture and siphonal canal. When known, the characters of the operculum and radula are also used.

The morphology of the radula is described starting from the rachidian tooth followed by the lateral teeth.

Unless otherwise mentioned, the species descriptions are based on all the examined specimens or on a representative selection of them, including the holotype and the other specimens of the type material.

All the material studied is deposited in the MNHN unless otherwise indicated.

\section{ABbreVIaTIONS}

\section{Repositories}

Coll. RH Collection Roland Houart, Ezemaal, Belgium;

IRD Institut de Recherche pour le Développement (formerly ORSTOM);

MNHN Muséum national d'Histoire naturelle, Paris;

ORSTOM Office de la Recherche scientifique et technique d'OutreMer (now IRD).

$$
\begin{array}{ll}
\text { Field work } & \\
\text { CP } & \text { chalut à perche (Beam trawl); } \\
\text { DW } & \text { drague Warén (Warén dredge). }
\end{array}
$$




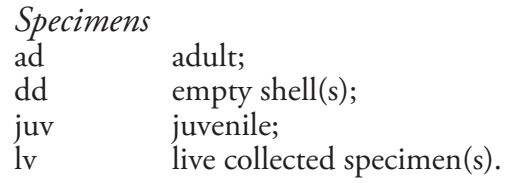

Terminology used to describe the spiral cords and the apertural denticles (after Merle 2001 and 2005) (Fig. 2A-E).

Terminology in parentheses: variable feature.

Convex part of teleoconch whorl and siphonal canal

ab abapical;

abis abapical infrasutural secondary cord (on subsutural ramp);

ABP abapertural primary cord on the siphonal canal;

abs abapertural secondary cord on the siphonal canal;

ad adapical;

adis adapical infrasutural secondary cord (on subsutural ramp);

ADP adapertural primary cord on the siphonal canal;

ads adapertural secondary cord on the siphonal canal;

IP infrasutural primary cord (primary cord on subsutural ramp);

MP median primary cord on the siphonal canal;

$\mathrm{ms} \quad$ median secondary cord on the siphonal canal;

P primary cord;

P1 shoulder cord;

P2-P7 primary cords of the convex part of the teleoconch whorl;

$s \quad$ secondary cord;

s1-s7 secondary cords of the convex part of the teleoconch whorl (example: $s 1=$ secondary cord between P1 and P2; 2 = secondary cord between P2 and P3, etc.);

SP subsutural cord;

t tertiary cord.

Aperture

D1 to D6 abapical denticles;

ID infrasutural denticle.

Morphology of the radula (Fig. 1)

$\mathrm{cc} \quad$ central cusp;

ild inner lateral denticle;

lc lateral cusp;

ld lateral denticle;

LT lateral tooth;

ma marginal area;

mc marginal cusp;

md marginal denticles;

old outer lateral denticle;

RT rachidian tooth.

\section{SYSTEMATICS}

Family MURICIDAE Rafinesque, 1815

Genus Vokesimurex Petuch, 1994

TyPE SPECIES. - Murex messorius Sowerby II, 1841, Western Atlantic (by original designation).

\section{Vokesimurex rectaspira $\mathrm{n}$. sp.}

(Figs 3A-G; 5A; 14A)

TyPE MATERIAL. - Holotype (lv) MNHN-IM-2009-14495 BOLD ID BOMGA023-15, GenBank accession number KP697994 for COI gene KC860506 (Fig. 3A, B) and 7 paratypes MNHN: 1 (lv)

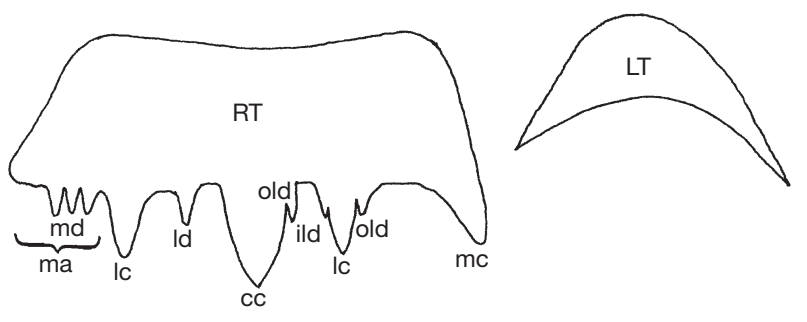

FIG. 1. - Schematic drawing of a muricid radula (after Kool 1993).

IM-2009-14501 BOLD ID BOMGA022-15, GenBank accession number KP697995 for COI gene KC860506; 3 (lv) \& 3 (dd) IM2000-30001; 1 paratype coll. RH (all from type locality).

TyPe LOCALITY. - Southern Madagascar, Southwest of Pointe Bar-

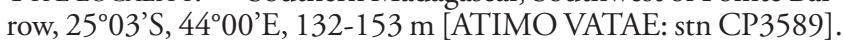

MATERIAL EXAMINED. - Known only from the type material.

Distribution. - Southern Madagascar, taken alive at 132-153 m.

ETYMOLOGY. - Latin, rectaspira, rectus (straight) and spira (spire). This species is named for its flattened spire outline.

DESCRIPTION

Shell small for the genus, up to $41.2 \mathrm{~mm}$ in height at maturity (holotype MNHN). Height/width ratio 2.9 (holotype MNHN). Slender, lanceolate, weakly spinose, lightly built. Shoulder ramp strongly sloping, weakly concave.

Beige or light tan with brown or dark brown spiral cords. Aperture glossy white.

Spire high with 2.10 protoconch whorls and teleoconch with up to six weakly convex and weakly shouldered whorls. Suture slightly impressed. Protoconch moderately broad, weakly conical, whorls rounded, last whorl minutely punctate, glossy, maximum width of last whorl $1000 \mu \mathrm{m}$ and first whorl $700 \mu \mathrm{m}$ (holotype). Terminal lip heavy, narrow, erect and curved.

Axial sculpture of teleoconch whorls consisting of high, rounded varices and ribs, each varix with a single, short, acute, narrow, narrowly open primary shoulder spine (P1). First whorl with 11 or 12 ribs, second with 9-12, third with 8-10, fourth to last whorl with three narrow, rounded, high varices and two intervariceal, high, narrow ribs. Spiral sculpture of narrow, smooth, primary, secondary and tertiary cords. First and second teleoconch whorls with IP, P1, P2, (S2), P3, P4, third whorl with (adis), IP, P1, (s1), P2, s2, P3, (s3), P4, fourth and fifth with adis, IP, abis, P1, S1, P2, s2, P3, s3, P4, last whorl with adis, IP, abis, P1, s1, P2, s2, P3, s3, P4, s4, P, s5, P6, s6, P7, s7, ADP, ads, MP, ms, ABP, abs, EAB1, eabs1, EAB2, eabs2, EAB3, eabs3, followed by several shallower spiral cords. Only P1 ending as short, acute, narrow variceal shoulder spine.

Aperture moderately small, roundly-ovate. Columellar lip narrow, flaring, smooth. Rim erect, a small portion adherent at adapical extremity. Low parietal tooth at extreme adapical extremity. Anal notch shallow, broad. Outer lip erect, smooth within or with seven very weak, elongate denticles: ID, D1-D6.

Siphonal canal long, narrow, narrowly open. 
Operculum dark brown, roundly-ovate with subapical nucleus. Attached with about four growth lines and broad, callused rim.

Radula (Fig. 14A) typical for the genus, with a rachidian bearing a long, triangular central cusp, a small lateral denticle and a broad, triangular, medium sized lateral cusp, marginal area smooth. Lateral tooth sickle shaped, broad.

\section{REMARKS}

Vokesimurex rectaspira n. sp. differs from the superficially similar V. gallinago fernandesi Houart, 1990 from Mozambique (Fig. $3 \mathrm{H}, \mathrm{I}$ ) by having a more regularly-shaped protoconch, with a narrower, more strongly curved terminal lip with slightly more numerous whorls, 2.10-2.15 as opposed to 1.75-2.0 in $V$ gallinago fernandesi and with a narrower first whorl (width $700 \mu \mathrm{m}$ vs 900-1100 $\mu \mathrm{m}$ ). Vokesimurex rectaspira n. sp. is also more slender with a higher spire consisting of more numerous teleoconch whorls for a similar shell height and also differs by having a flatter as opposed to a more rounded or occasionally weakly concave spire outline in $V$. gallinago fernandesi, and by having narrower primary spiral cords on the siphonal canal.

Another Vokesimurex species occurring in northern Madagascar, namely $V$. dolichourus (Ponder \& Vokes, 1988) (Fig. 3J-L) differs also in many ways in its protoconch and teleoconch characters.

\section{Vokesimurex aliquantulus $\mathrm{n}$. sp.}

(Figs 3M, N; 4A-E; 5B)

TYPE MATERIAL. — Holotype (lv), MNHN-IM-2007-36971 BOLD ID BOMGA020-15, GenBank accession number KP697992 for COI gene KC860506 and 5 paratypes (lv) MNHN: 3 MNHN-IM-2000-30002, 1 MNHN-IM-2007-36950, 1 MNHN-IM-2007-36958 BOLD ID BOMGA021-15, GenBank accession number KP697993 for COI gene KC860506; 1 paratype coll. RH (all from type locality).

TyPe Locality. - Madagascar, between Nosy Be and Banc du Leven, 12³9'S, 48²2'E, 70-74 m [MIRIKY: stn CP3206].

Material examined. - Known only from the type material.

Distribution. - Northern Madagascar, taken alive at 70-74 m.

Etymology. - Latin, aliquantulus, little, small. This species is named for its small size relative to the other Murex s.s. species.

\section{DESCRIPTION}

Shell small for the genus, up to $33.1 \mathrm{~mm}$ in height. Height/ width ratio 2.3 (holotype). Slender, lanceolate, narrowlyovate, nodose, lightly built. Shoulder ramp strongly sloping, weakly convex.

White with occasionally a very light brown darker band on P1 and P2, more obvious on P2 and on axial varices, and between P6 and P7. Aperture white.

Spire high with 1.75-2.00 protoconch whorls and teleoconch up to 6.25 , convex, narrow, weakly shouldered, nodose whorls. Suture impressed. Protoconch small, whorls rounded, smooth, occasionally with a narrow keel abapically, width $700 \mu \mathrm{m}$. Terminal lip heavy, broad, erect, weakly curved.
Axial sculpture of teleoconch whorls consisting of low, narrow, rounded ribs and high, rounded, weakly spinose varices. First whorl with 11 or 12 ribs, second with 11-13, third with 10-12, early varices on fourth whorl with two or three intervariceal ribs. Last whorl with three high, narrow, rounded varices and two broad intervariceal ribs, occasionally with a third narrow one. Spiral sculpture of moderately high, narrow, weakly nodose primary, secondary and tertiary cords. First whorl with P1-P4, P4 partially covered by the following teleoconch whorl, second and third whorls with IP, P1-P4, fourth with adis, IP, P1, P2, P2, P3, s3, P4, fifth with adis, IP, abis, P1, P2, P3, s3, P4, sixth and seventh with t, adis, (t), IP, abis, P1, s1, P2, s2, P3, s3, P4, s4, P5, s5, P6, s6, P7, s7, ADP, ads, MP, ms, ADP, ads. Other spiral cords decreasing in strength and height abapically. Intersection of axial varices and P1 giving rise to a short, narrow, narrowly open, acute shoulder spinelet from fourth or fifth to last teleoconch whorl.

Aperture narrow, roundly-ovate. Columellar lip narrow, strongly flaring with two or three elongate, weak knobs abapically. Rim erect, a small portion adherent adapically. Low parietal tooth at extreme adapical extremity. Anal notch shallow, broad. Outer lip strongly erect, weakly crenulated, bearing eight weak, elongate, narrow denticles within: ID, D1-D7. Siphonal canal narrow, straight, weakly dorsally recurved, weakly open, occasionally with a single, acute, short spine adapically.

Operculum and radula not examined.

\section{REMARKS}

Vokesimurex aliquantulus n. sp. differs from $V$. gallinago fernandesi (Fig. 3H, I) in being more lightly-built, in having a narrower and more acute spire, a narrower siphonal canal and a comparatively narrower aperture. The protoconch is also much smaller, $700 \mu \mathrm{m}$ wide $\times 750 \mu \mathrm{m}$ high as opposed to $1000-1200 \mu \mathrm{m}$ wide $\times 1000-1100 \mu \mathrm{m}$ high. It also has a very narrow spiral keel abapically, not observed in $V$. gallinago fernandesi.

Vokesimurex aliquantulus n. sp. differs from Vokesimurex rectaspira n. sp. (Fig. 3A-G) in the same characters and in having a spire that is weakly incurved and not almost straight as in Vokesimurex aliquantulus n. sp.

It differs from Vokesimurex gallinago gallinago (Sowerby III, 1903) and $V$. dentifer (Watson, 1883), not present in the western Indian Ocean, in also having a smaller protoconch (700 $\mu \mathrm{m}$ wide vs 1100-1200), a narrower aperture and a narrower siphonal canal. From $V$. gallinago gallinago it also differs in having almost spineless varices, rather than the more spinose, occasionally weakly webbed varices of $V$. gallinago gallinago.

Vokesimurex rectirostris (Sowerby II, 1841) (Fig. 4F, G) and $V$. sobrinus (A. Adams, 1863) (Fig. 4H, I) both have a rounded protoconch with a strong keel abapically but in $V$. aliquantulus n. sp. the keel is more delicate, narrower and situated more abapically, and the protoconch is also relatively smaller (700 vs $1100-1400 \mu \mathrm{m}$ wide). Both these species, restricted to the region from Taiwan to southern Japan, are also more spinose. 

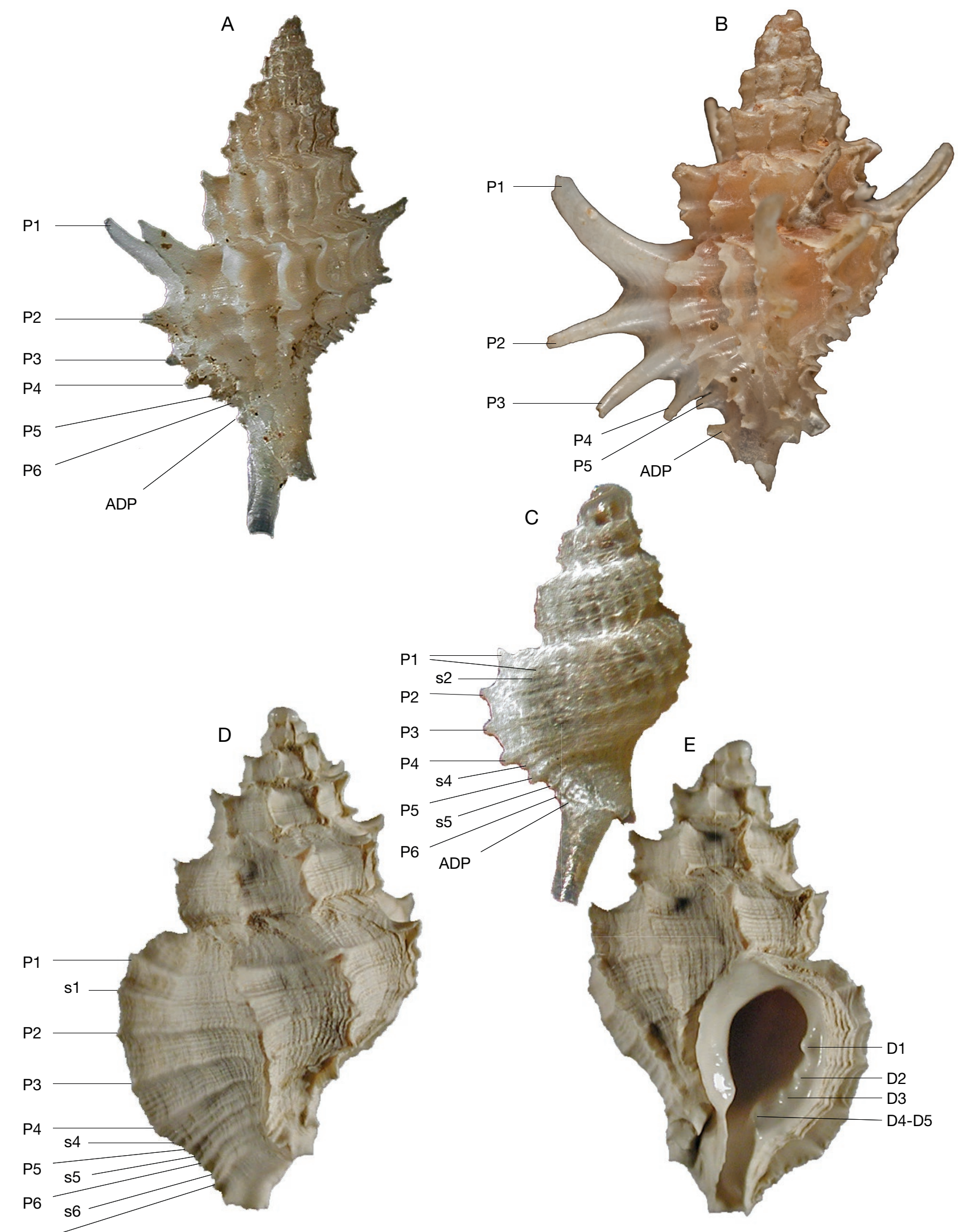

FIG. 2. - Spiral cords and apertural denticles morphology: A, Bouchetia wareni n. sp. (holotype), 18.1 mm; B, Bouchetia vaubanensis (Houart, 1986) (holotype), $10.5 \mathrm{~mm}$; C, Murexsul mananteninaensis n. sp. (holotype), $5.2 \mathrm{~mm}$; D, E, Flexopteron akainakares n. sp. (holotype), $12,2 \mathrm{~mm}$. Abbreviations: see Material and methods. 


\section{Genus Timbellus de Gregorio, 1885}

Type SPECIES. - Murex latifolius Bellardi, 1872, Middle Miocene, Italy (by subsequent designation; Vokes 1964: 14).

\section{REMARKS}

The genus Timbellus was reinstated by Merle et al. (2011) for the species generally classified in Pterynotus s.s. Swainson, 1833 but usually with a less scabrous shell morphology and with three major axial varices "appearing early during the ontogeny”. This distinction from the Pterynotus s.s. group was noted by Barco et al. (2010), with Pterynotus fulgens Houart, 1988 in their DNA analysis even falling outside the Muricinae Rafinesque, 1815. The classification used here follows Barco et al. (2010) pending availability of more material for further DNA research and the publication of additional results.

On the other hand, the classification of Merle et al. (2011) mixes the species with a trivaricate axial sculpture starting already on the first teleoconch whorl, such as Timbellus latifolius, the type species, and some Recent species like T. fulgens (Houart, 1988). In Timbellus goniodes n. sp., here described, and a few other species such as T. bednalli (Brazier, 1878), T. phyllopterus (Lamarck, 1822) and Pterynotus alatus (Röding, 1798), the type species of Pterynotus, the trivaricate sculpture appears only on the third or fourth teleoconch whorl. Their generic placement awaits confirmation by genetic analysis.

\section{Timbellus pannuceus n. sp.}

(Figs 4J-O; 7A)

TYPe MATERIAL. - Holotype (lv) MNHN-IM-2007-36940 BOLD ID BOMGA026-15, GenBank accession number KP697989 for COI gene KC860506 and 5 paratypes MNHN, 1 paratype coll. RH (as listed below).

Type Locality. - Madagascar, between Nosy Be and Banc du Leven, $12^{\circ} 40^{\prime} \mathrm{S}$, 48²'E, 492-524 m [MIRIKY: stn CP3184].

MATERIAl EXAmined. - Northwest Madagascar. MIRIKY: stn CP3184, between Nosy Be and Banc du Leven, $12^{\circ} 40^{\prime}$ 'S, 48 $12^{\prime} \mathrm{E}$, 492$524 \mathrm{~m}, 2 \mathrm{lv}, 1 \mathrm{dd}$ (holotype MNHN-IM-2007-36940 and 1 paratype (lv) MNHN-IM-2007-38031 BO LD ID BOMGA025-15, GenBank accession number KP697990 for COI gene KC86050, 1 paratype (dd) MNHN-IM 2000-30003. - Stn CP3188, between Nosy Be and Banc du Leven, $12^{\circ} 31^{\prime}$ S, $48^{\circ} 22^{\prime} \mathrm{E}, 298-301 \mathrm{~m}, 2 \mathrm{lv}$ (1 paratype MNHN-IM-2000-30004; 1 paratype Coll. RH). — Stn DW3197, West of Cap d'Ambre, $12^{\circ} 07^{\prime} \mathrm{S}, 48^{\circ} 58^{\prime} \mathrm{E}, 362-431 \mathrm{~m}, 3 \mathrm{dd}$. - Stn CP3209, between Nosy Be and Banc du Leven, 12 $43^{\prime}$ S, 48 $14^{\circ} \mathrm{E}$, 291-353 m, (2 lv paratypes MNHN-IM-2000-30005). - Stn CP3223, between Nosy Be and Banc du Leven, $12^{\circ} 46^{\prime}$ S, 48 $11^{\circ} \mathrm{E}$, 430-488 m, 1 dd.

Distribution. - North-western Madagascar, taken alive at 301$492 \mathrm{~m}$, shells at $431-492 \mathrm{~m}$.

ETYMOLOGY. - Latin, pannuceus, wrinkled. This species is named for the wrinkled surface of the shell.

\section{DESCRIPTION}

Shell medium sized for the genus, up to $22.6 \mathrm{~mm}$ in height at maturity (paratype MNHN). Height/width ratio 1.4 (holotype). Slender, narrowly-ovate, lightly built. Shoulder ramp strongly sloping, weakly concave.

Ivory-white, occasionally with a light tan spiral band between P4 and P5 and occasionally on shoulder ramp. Aperture white.

Spire high with 1.5 protoconch whorls and teleoconch with up to five narrow, very weakly shouldered whorls. Suture weakly adpressed. Protoconch small, whorls rounded, smooth, glossy, maximum width $900 \mu \mathrm{m}$. Terminal lip narrow, low, weakly curved.

Axial sculpture of teleoconch whorls consisting of very narrow, webbed varices starting from the first whorl. First to last teleoconch whorls with three varices. No intervariceal sculpture except narrow, low, growth striae. Spiral sculpture of moderately high, narrow, smooth primary and secondary cords. First whorl with very low P1, second and third with $\mathrm{P} 1$ and $\mathrm{P} 2$, s1 occasionally starting, fourth with P1, (s1), P2, s2, P3, last whorl with P1, (s1), P2, s2, P3, s3, P4, (s4), P5, P6, ADP, MP, ABP, (ads).

Aperture moderately large, roundly-ovate. Columellar lip narrow, more broadly expanded adapically, weakly flaring, rim partially weakly erect, adherent at adapical extremity. Anal notch shallow, broad. Outer lip smooth, occasionally with weak or strong denticles within: ID broad, low, D1D6 narrower; aperture occasionally smooth or with only a few denticles visible, others obsolete. Siphonal canal moderately long, broad, weakly bent dorsally and abaxially, narrowly open, with variceal webbing extending to $50-60 \%$ of its length.

Operculum and radula not examined.

\section{REMARKS}

Eight Indo-West Pacific species are included in Timbellus, all with a similar shell morphology consisting of a protoconch of 1.5 to 1.75 smooth whorls, smooth or almost smooth teleoconch whorls and thin, webbed variceal wings. These are T. vespertilio (Kuroda, 1959), T. Alemingi (Beu, 1967), T. fulgens (Houart, 1988), T. levii (Houart, 1988), T. marshalli (Houart, 1989), T. stenostoma (Houart, 1991), T. crauropterus (Houart, 1991) and T. rubidus (Houart, 2001).

Four of these species (T. Alemingi, T. marshalli, T. crauropterus and $T$. rubidus) do not need to be compared with T. pannuceus n. sp. due to important differences in shell characters. The remaining four differ from $T$. pannuceus n. sp. as follows.

Timbellus vespertilio (Fig. 6A, B) differs in having more strongly shouldered teleoconch whorls with a relatively broader shoulder ramp and a more obvious and broader shoulder cord (P1). It also has fewer obvious spiral cords on the teleoconch whorls and on the abapertural face of the variceal wings. Timbellus vespertilio is known only from southern Japan, the East China Sea and Taiwan.

Timbellus fulgens (Fig. 4P, Q) was described from New Caledonia and was identified from South Africa by Houart 


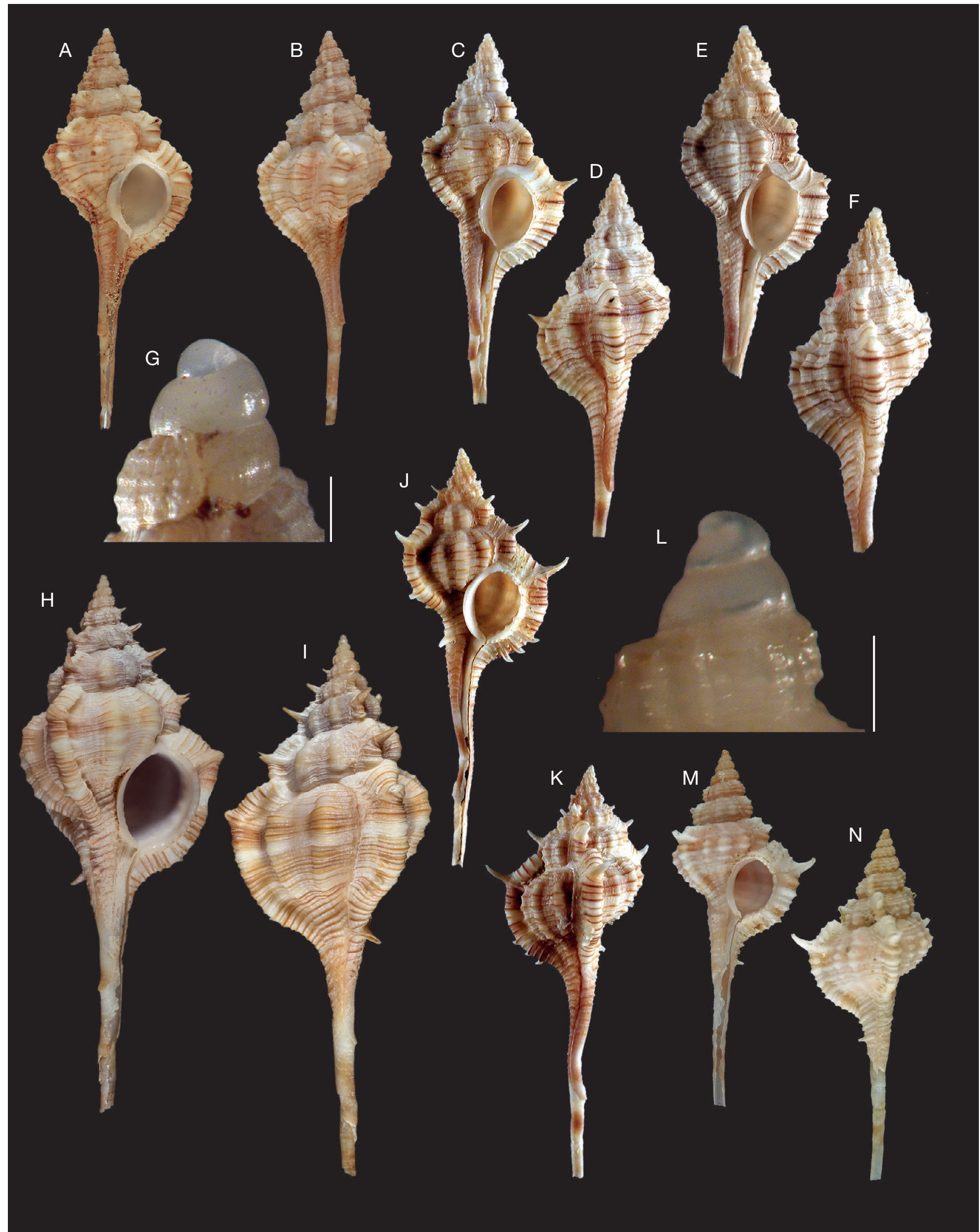

FiG. 3. - A-G, Vokesimurex rectaspira n. sp.; ATIMO VATAE: stn CP3589; A, B, holotype MNHN IM-2009-14495, 41.2 mm; C, D, paratype MNHN IM-200030001, 38.2 mm; E, F, paratype MNHN IM-2000-30001, 24.8 mm; G, protoconch; H, I, Vokesimurex gallinago fernandesi (Houart, 1990); Mozambique, 93-112 m, holotype MNHN IM-2000-0089, 63.2 mm; J-L, Vokesimurex dolichourus (Ponder \& Vokes, 1988); J, K, MIRIKY, stn CP3288, $46-54$ m, 56.2 mm; L, protoconch; M, N, Vokesimurex aliquantulus n. sp.; MIRIKY, stn CP3206, 70-74 m, holotype MNHN IM-2007-36971, 28.3 mm. Scale bars: G, L, 500 m. 
(1991). Similar specimens are now also recorded from Madagascar. However it differs from T. pannuceus n. sp. in having a much smoother shell and smoother variceal wings with much lesser obvious primary cords and obsolete secondary cords.

Timbellus levii, a species currently only known from New Caledonia and Tonga (Houart \& Héros 2008) has a larger shell, reaching $36 \mathrm{~mm}$ in height, with smooth teleoconch whorls, almost smooth, broader variceal wings and with a much narrower and higher aperture.

Timbellus stenostoma from New Caledonia has a much smaller and smoother shell, reaching $15 \mathrm{~mm}$ in height, with a much smaller aperture and a longer siphonal canal.

\section{Timbellus goniodes n. sp.}

(Figs 6C-G; 7B)

TYPe MATERIAL. - Holotype (dd) MNHN-IM-2000-30006, 3 paratypes MNHN, 1 paratype coll. RH (as listed below).

Type LOCALITY. - South Madagascar, South of Cap Sainte-Marie,

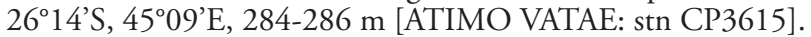

MATERIAL EXAMINED. - South Madagascar. ATIMO VATAE: stn DW3552, South of Faux-Cap, 2607'S, 4539'E, 264-280 m, 2 dd (1 paratype MNHN-IM-2000-30007, 1 Coll. RH). — Stn DW3553, South of Faux-Cap, $26^{\circ} 08^{\prime} S$, 45 $39^{\circ} \mathrm{E}, 280-333 \mathrm{~m}, 1 \mathrm{dd}$ fragment (paratype MNHN-IM-2000 30008). - Stn CP3615, South of Cap Sainte-Marie, $26^{\circ} 14$ 'S, 4509'E, 284-286 m, 2 dd (holotype MNHN-IM-2000-30006, 1 paratype MNHN-IM-2000-30009).

Distribution. — Southern Madagascar, 280-284 m (shells only).

ETYMOLOGY. - Greek, goniodes, angular. This species is named for the angular shape of the teleoconch whorls.

\section{DESCRIPTION}

Shell medium sized for the genus, up to $23.7 \mathrm{~mm}$ in height at maturity. Height/width ratio 1.6-2.0. Slender, narrowlyovate, spinose, lightly built. Shoulder strongly sloping, weakly concave or straight.

Milky white or pinkish white. Aperture white.

Spire high, acute, with 1.5 protoconch whorls and teleoconch up to six weakly convex, angular, weakly shouldered whorls. Suture impressed. Protoconch small, whorls rounded, smooth, glossy, width 600-650 $\mu \mathrm{m}$. Terminal lip delicate, thin, weakly raised, weakly curved.

Axial sculpture of teleoconch whorls consisting of high, narrow, lamellose varices, each with a long, narrow, open shoulder spine. First whorl with six or seven varices, second with five or six, third with four. From fourth to last teleoconch whorl, three narrow, high, lamellose, webbed varices. Spiral sculpture of low and high, narrow, rounded primary cords. First whorl with P1-P3 of approximately the same strength, second with P1-P3, P2 becoming broader and higher. Third and fourth whorls with shallow, almost obsolete P1, P2 and P3 similar in strength and height, P3 partially covered by following whorl, fifth whorl with very shallow P1 and broad, high, rounded P2 and P3, last whorl with weak P1, more obvious on lamellose, webbed varices, P2 and P3 higher and broader, P4-P6 weak, decreasing in strength abapically, broader on webbed apertural varix. P1 ending as a short, narrow, adapically bent shoulder spine. P2-P6 ending as a shorter, backward recurved, narrowly open spine.

Aperture ovate, angular. Columellar lip narrow, flaring, smooth or with two weak knobs abapically, rim partially erect, adherent at adapical extremity. Anal notch moderately deep, broad. Outer lip strongly erect, smooth with six weak or strong denticles within: ID, D1-D5. ID very low, broad, D1-D5 variable in strength and height. Siphonal canal moderately short, broad, weakly abaxially bent and dorsally recurved at tip, narrowly open, with variceal webbing extending to 80$90 \%$ of its length.

Operculum and radula unknown.

\section{REMARKS}

Timbellus goniodes n. sp. differs in many ways from the other Indo-West Pacific Timbellus species. From T. fulgens (Fig. 4P, Q) living in the same geographical area, T. goniodes n. sp. differs in having a narrower shell with a higher spire, a smaller protoconch $(600-650 \mu \mathrm{m}$ wide vs $1000 \mu \mathrm{m})$, a narrower subsutural ramp, strong and relatively broader spiral cords with higher P2 and P3, a more angular aperture and more strongly adapically bent shoulder spines, and chiefly in having four to seven varices on the three adapical teleoconch whorls as opposed to three in T. fulgens.

From T. crauroptera (Fig. 6H) from New Caledonia, a species that also has upward bent shoulder spines and a more angular aperture, $T$. goniodes $n$. sp. differs in having somewhat narrower shoulder spines, more strongly obvious spiral cords, less convex teleoconch whorls without intervariceal varices, a higher spire and variceal webbing extending to almost $80 \%$ of the length of the siphonal canal rather than extending to 10 or $20 \%$ of its length in T. crauroptera with the additional presence of ADP and MP. Moreover T. crauroptera also has three variceal wings starting at the first teleoconch whorl.

\section{Genus Bouchetia Houart \& Héros, 2008}

TYPE SPECIES. - Poirieria (Paziella) vaubanensis Houart, 1986, New Caledonia (by original designation).

\section{REMARKS}

Although molecular phylogenetic research is improving our understanding of the classification of supraspecific taxa in the Muricidae (Barco et al. 2010), based on shell morphology, Bouchetia and Flexopteron Shuto, 1969 (see below) were treated by Merle et al. (2011) as subgenera of Paziella Jousseaume, 1880 .

Pending the result of DNA analyses we feel it premature to adopt this new classification based only on shell characters. We will therefore continue to treat Bouchetia as a full genus as used by Houart \& Héros (2008: 450). 


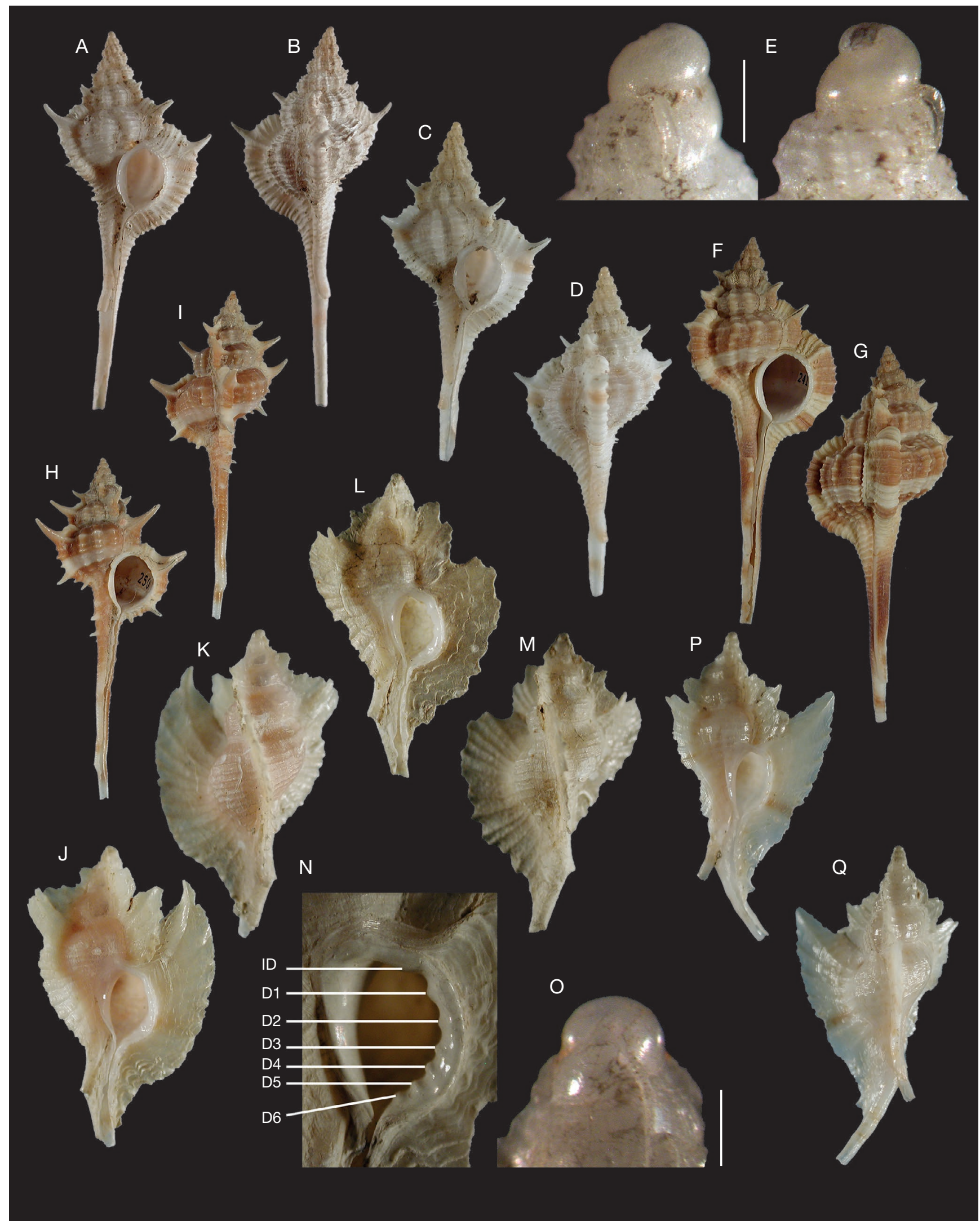

FIG. 4. - A-E, Vokesimurex aliquantulus n. sp., MIRIKY, stn CP3206, 70-74 m; A, B, paratype MNHN IM-2000-30002, 33.1 mm; C, D, paratype MNHN IM-200030002, 22.6 mm; E, protoconch; F, G, Vokesimurex rectirostris (Sowerby, 1881), Taiwan Strait, Coll. RH, 68 mm; H, I, Vokesimurex sobrinus (A. Adams, 1863); Tosa, Japan, Coll. RH, 51.3 mm; J-O, Timbellus pannuceus n. sp.; J, K, MIRIKY, stn CP3184, 492-524 m, holotype MNHN IM-2007-36940, 18.9 mm; L, M, paratype MNHN IM-2007-38031, 20.6 mm; N, detail of the aperture; O, protoconch; P, Q, Timbellus fulgens (Houart, 1988); MIRIKY, stn DW3215, $316-433$ m, 22.5 mm. Abbreviations: See Material and methods. Scale bars: $\mathrm{E}, \mathrm{O}, 500 \mu \mathrm{m}$. 


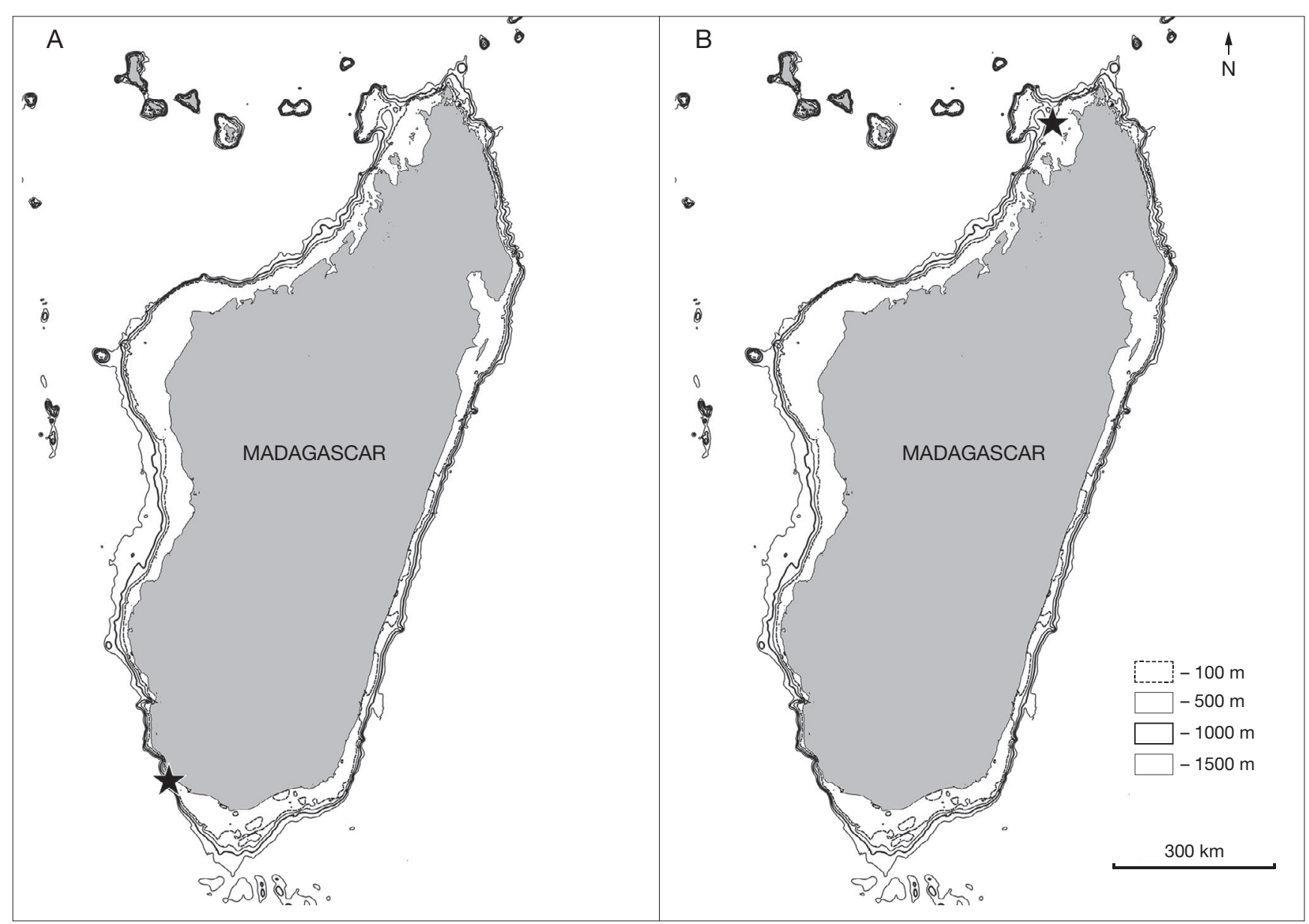

FIG. 5. - Distributions of: A, Vokesimurex rectaspira n. sp.; B, Vokesimurex aliquantulus n. sp. Symbols: ^, type locality.

Bouchetia wareni $\mathrm{n} . \mathrm{sp}$.

(Figs 2A; 6I-M; 9A)

Trophonopsis polycyma Kuroda, 1953: 187, fig. 1. - Houart 1985: 246, fig. 10, 10A (not Trophonopsis polycyma Kuroda, 1953).

Type MATERIAL. - Holotype (lv) MNHN-IM-2007-36941 and 3 paratypes MNHN, 1 paratype coll. RH (listed as below).

Type LOCALity. - Madagascar, between Nosy Be and Banc du Leven, $12^{\circ} 30^{\prime}$ S, 4818'E, 346-376 m [MIRIKY: stn CP3189].

MATERIAl eXAmined. - Mozambique Channel. BENTHEDI: stn DS72, Mayotte, NNE du Récif Nord, $12^{\circ} 32^{\prime}$ S, $45^{\circ} 02^{\prime} \mathrm{E}, 300$ $350 \mathrm{~m}, 2 \mathrm{dd}$.

Northwest of Madagascar. MIRIKY: stn CP3183, between Nosy Be and Banc du Leven, $12^{\circ} 38^{\prime} \mathrm{S}, 48^{\circ} 14$ 'E, 420-436 m, $1 \mathrm{lv}$ (paratype MNHN-IM-2007-36979 BOLD ID BOMGA024-15, GenBank accession number KP697988 for COI gene KC860506). - Stn CP3184, between Nosy Be and Banc du Leven, 12 ${ }^{\circ} 40^{\prime} \mathrm{S}, 48^{\circ} 12^{\prime} \mathrm{E}$, 492-524 m, $1 \mathrm{lv}$ (paratype Coll. RH). - Stn CP3189, between Nosy Be and Banc du Leven, 12 $30^{\prime}$ S, 48 ${ }^{\circ} 18^{\prime} \mathrm{E}, 346-376 \mathrm{~m}, 1 \mathrm{lv}$ (holotype MNHN-IM-2007-36941). - Stn DW3197, West of Cap d'Ambre, $12^{\circ} 07^{\prime}$ S, 48 58'E, 362-431 m, 1 dd. - Stn DW3217, between Nosy Be and Banc du Leven, 12³3'S, 47 $56^{\prime} \mathrm{E}, 391-438 \mathrm{~m}$, 1 dd (paratype MNHN-IM-2000-30010). - Stn DW3226, between Nosy Be and Banc du Leven, 12 $2^{\circ} 51^{\prime} \mathrm{S}, 48^{\circ} 12^{\prime} \mathrm{E}, 341-345 \mathrm{~m}$, 1 dd (paratype MNHN-IM-2000-30011).
South Madagascar. ATIMO VATAE: stn DW3524, sector of Manantenina, $24^{\circ} 23^{\prime} \mathrm{S}, 47^{\circ} 32^{\prime} \mathrm{E}, 307-319 \mathrm{~m}, 1 \mathrm{dd}$, juv. — Stn

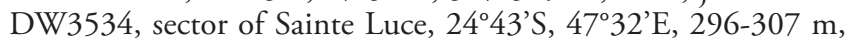

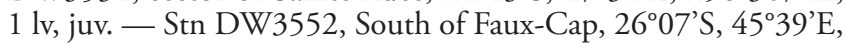
264-280 m, 2 dd, juv. - R.V. Vauban, 1972-73, $22^{\circ} 17^{\prime}$ 'S, $43^{\circ} 03^{\prime} \mathrm{E}$, 600-605 m, 1 dd.

Distribution. - Madagascar and Mayotte, live in 307-492 m, shells in 280-600 m.

Etymology. - This species is named after Anders Warén, in recognition of his help in extracting, mounting and imaging numerous radulae for the senior author. He also has participated in many expeditions organized by MNHN, including ATIMO VATAE.

\section{DESCRIPTION}

Shell medium sized for the genus, with up to $18.5 \mathrm{~mm}$ in height at maturity (paratype MNHN). Height/width ratio 1.4-1.7. Broad, spinose, lightly built. Subsutural band narrow, weakly sloping, weakly concave. White or very light tan.

Spire high with 1.60-1.75 protoconch whorls and teleoconch up to six broad, weakly convex, strongly shouldered, spinose whorls. Suture impressed, partially obscured by small axial lamellae of following whorl. Protoconch small, whorls rounded, smooth. Maximum width 700-800 $\mu \mathrm{m}$. Terminal lip delicate, thin, very weakly curved. 


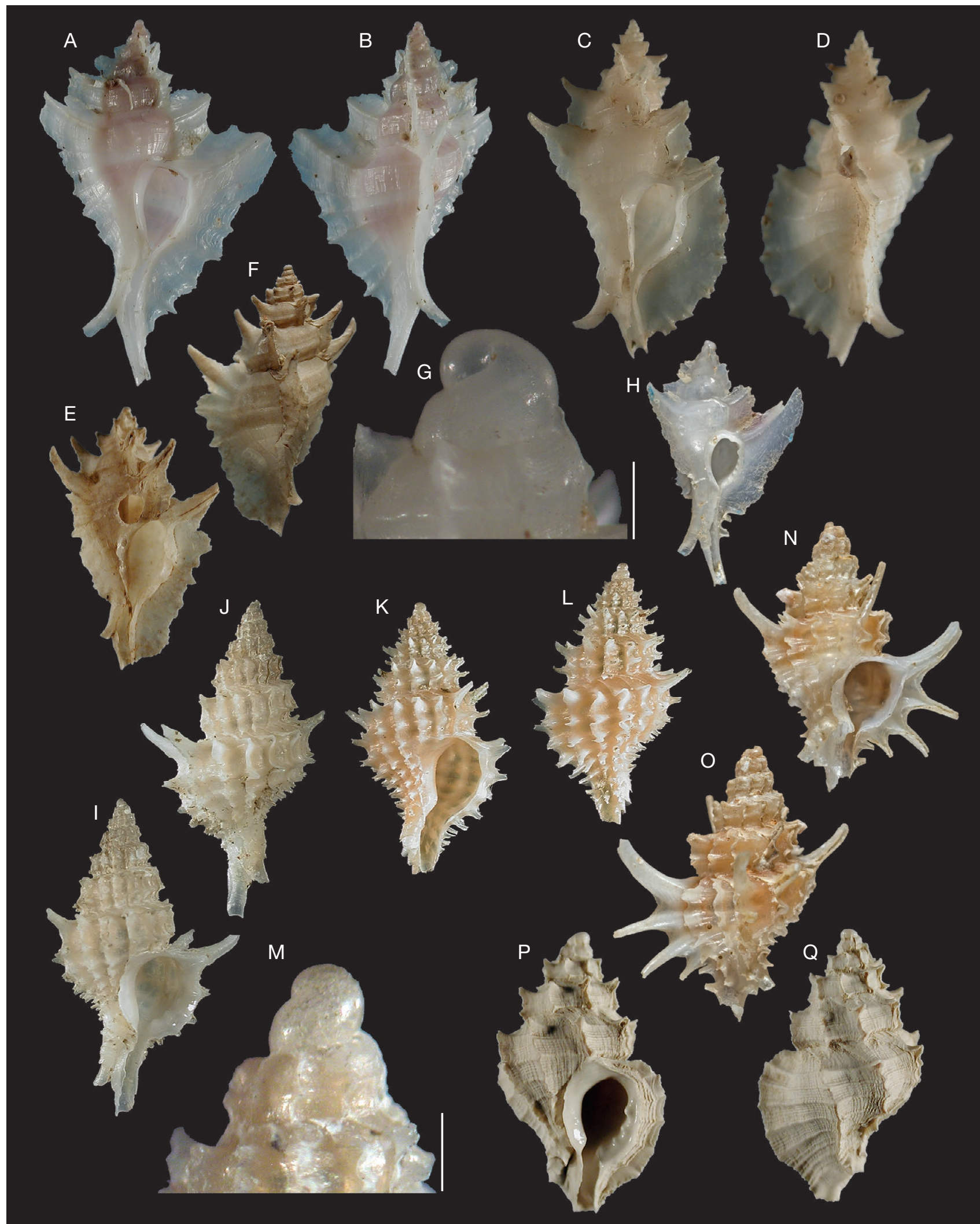

FIG. 6. - A, B, Timbellus vespertilio (Kuroda, 1959), East China Sea, Coll. RH, 28 mm; C-G, Timbellus goniodes n. sp., C, D, ATIMO VATAE, stn CP3615, 284286 m, holotype MNHN IM-2000-30006, 23.7 mm; E, F, ATIMO VATAE, stn DW3552, 264-280 m, paratype MNHN IM-2000-30007, 14.8 mm; G, protoconch; H, Timbellus crauroptera (Houart, 1991); New Caledonia, BIOCAL, stn DW64, 250 m, holotype MNHN IM-2000-0132, 11.4 mm; I-M, Bouchetia wareni n. sp., Madagascar, MIRIKY, stn CP3189, 346-376 m; I, J, holotype MNHN-2007-36941, 18.1 mm; K, L, MIRIKY, stn CP3183, paratype MNHN IM-2007-36941, 12.8 mm; M, protoconch; N, O, Bouchetia vaubanensis Houart, 1986; South of New Caledonia, VAUBAN 1976-1978, stn DR01, 480-500 m, holotype MNHN IM-2000-0885, 10.5 mm; P, Q, Flexopteron akainakares n. sp., ATIMO VATAE, stn DW3524, 307-319 m, holotype MNHN IM-2000-30012, 12.2 mm. Scale bars: G, M, 500 m. 


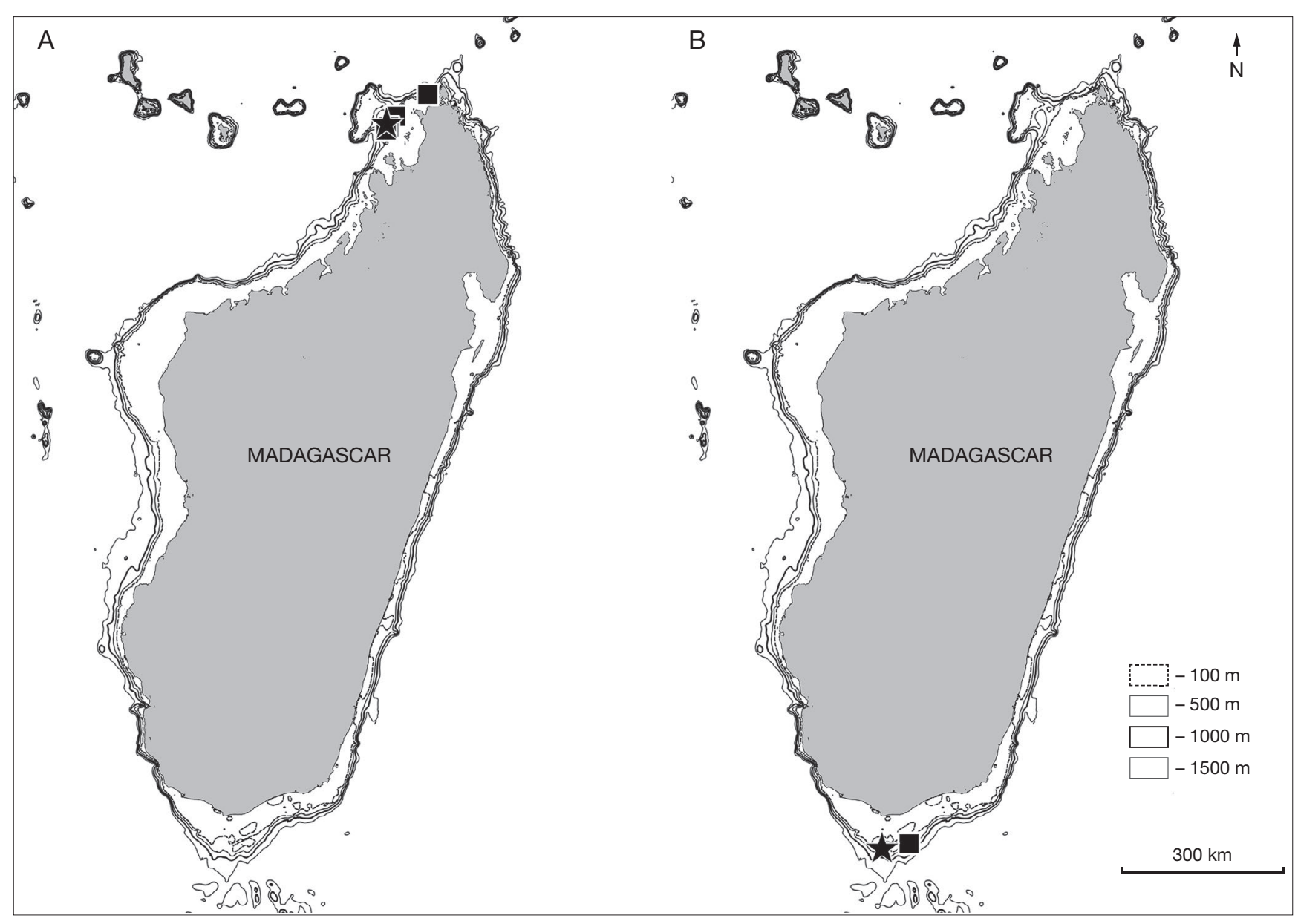

FIG. 7 - Distributions of: A, Timbellus pannuceus n. sp.; B, Timbellus goniodes n. sp. Symbols: $\star$, type locality; $\mathbf{\square}$, other occurences.

Axial sculpture of teleoconch whorls consisting of low, narrow lamellae, more strongly developed at intersection of axial lamellae and spiral cords, producing short or long, narrow, spine-like projections. Shoulder spine longest. Axial sculpture of first whorl with 8-10 lamellae, second with $11-13$, third with 13 or 14 , fourth $12-15$, fifth 15 and last whorl with 10-13. Spiral sculpture of moderately high, rounded, narrow, smooth primary cords. First to penultimate teleoconch whorl with P1-P3, P3 partially covered by following whorl. Last whorl with P1-P6, ADP, (MP). Secondary cords s1 or s2 rarely present. Primary cords decreasing in strength abapically. P1 broadest with long shoulder spine. Other spiral sculpture consisting of numerous lirae.

Aperture moderately small, broad, rounded. Columellar lip broad, flaring, smooth. Rim partially strongly erect, adherent at adapical extremity. Anal notch shallow, broad. Outer lip weakly erect, smooth with 4-6 weak, elongate, narrow denticles within: D1 (occasionally split), D2, D3, D4, D5 (D4 and D5 occasionally fused), rarely with low, weak, narrow ID. Siphonal canal moderately long or long, up to $33 \%$ of total shell height, narrow, weakly dorsally recurved, open.

\section{REMARKS}

Bouchetia vaubanensis (Houart, 1986) (Figs 2B; 6N, O) described from New Caledonia and also known from Fiji (Houart \& Héros 2008: 452) resembles the new species, but Bouchetia wareni $\mathrm{n}$. sp. is distinct in having a comparatively higher spire, a longer siphonal canal, a broader aperture and also in having a different spiral sculpture morphology. Bouchetia wareni n. sp. possesses six spiral cords on the convex part of the teleoconch whorl (P1P6) and two cords on the siphonal canal (ADP and MP), while B. vaubanensis clearly has five spiral cords on the convex part of the last teleoconch whorl (P1-P5) and a single one on the siphonal canal (ADP) (Fig. 2A, B). Merle et al. (2011: 174) illustrated the canal cord as P6 but this cord is clearly separated from the whorl, as in Paziella, for example Paziella pazi (Crosse, 1869) as shown by Merle et al. (2011: 162). This cord is here considered as a true siphonal canal spiral cord, here ADP.

Merle et al. (2011: 174, text fig. 60D) wrongly illustrated the radula of Pazinotus falcatiformis as Bouchetia vaubanensis. The radula of Bouchetia is peculiar in having a broad, long central cusp and long lateral cusps, but lacking lateral denticles (Fig. 14G).

Bouchetia wareni n. sp. was first illustrated by Houart (1985: 246, fig. 10) as Trophonopsis polycyma Kuroda, 1953, 


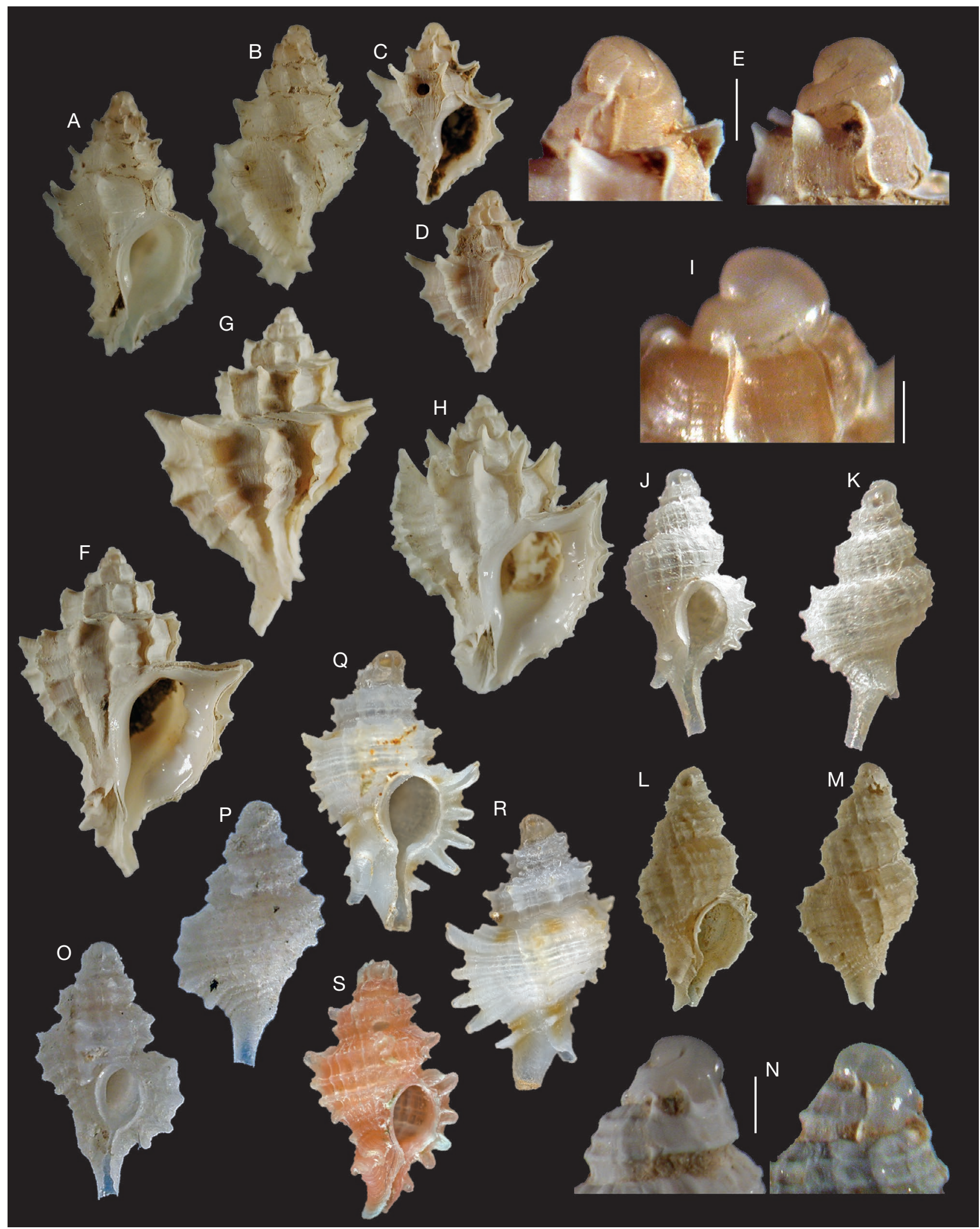

FIG. 8. - A-E, Flexopteron akainakares n. sp.: A, B, ATIMO VATAE, stn DW3515, 184-203 m, paratype MNHN IM-2000-30013, 10.2 mm (radula illustrated Fig. 14 B, C); C, D, ATIMO VATAE, stn DW3524, 307-319 m, 6.2 mm; E, protoconch; F-I, Flexopteron primanova (Houart, 1985): F, G, MIRIKY, stn CP3289, 332-379 m, 20.7 mm; H, MIRIKY, stn CP3192, 578-580 m, 16.9 mm; I, protoconch; J-N, Murexsul mananteninaensis n. sp.: J, K, ATIMO VATAE, stn DW3524, 307-319 m, holotype MNHN IM-2000-30015, 5.2 mm; L, M, ATIMO VATAE, stn DW3523, 200-220 m, paratype MNHN IM-2000-30016, 4.5 mm; N, protoconch; O, P, Murexsul queenslandicus Houart, 2004, Australia, Queensland, Southeast of Swain Reefs, $22^{\circ} 26.27^{\prime}-22^{\circ} 20.2^{\prime}, 153^{\circ} 17.13^{\prime}-152^{\circ} 17.6^{\prime} \mathrm{E}, 187 \mathrm{~m}$, paratype RH, 4.5 mm; Q, R, Murexsul charcoti (Houart, 1991), New Caledonia, BIOCAL, stn DW44, 440-450 m, holotype MNHN IM-2000-0067, 7.2 mm; S, Murexsul micra (Houart, 2001), New Caledonia, LAGON, stn 1374, 20-35 m, holotype MNHN IM-2000-0356, 3.7 mm. Scale bars: E, I, N, $500 \mu \mathrm{m}$. 


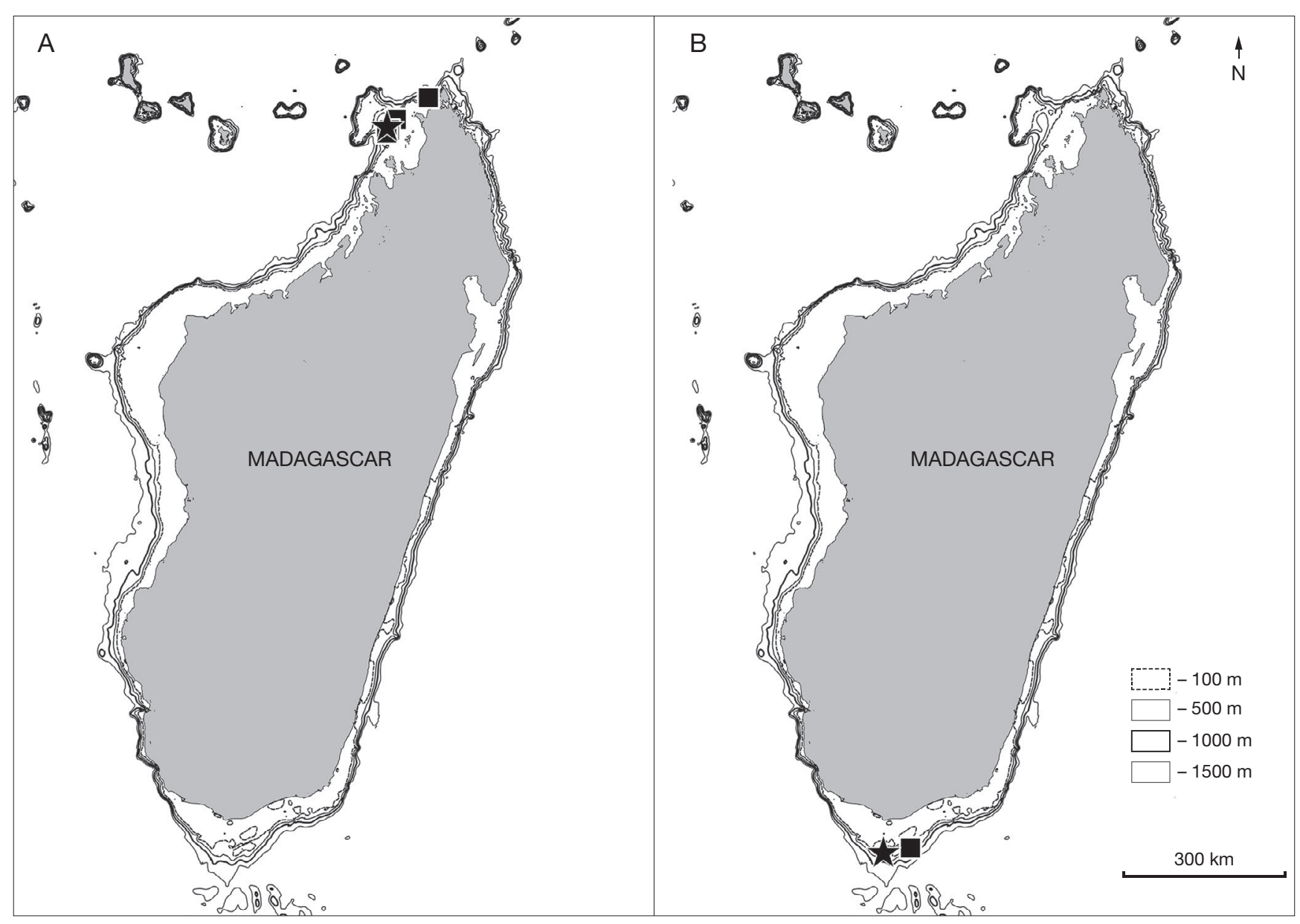

FIG. 9. - Distributions of: A, Bouchetia wareni n. sp.; B, Flexopteron akainakares n. sp. Symbols: $\star$, type locality; $\mathbf{\square}$, other occurences.

a species known only from the western Pacific. This juvenile specimen $(8.9 \mathrm{~mm}$ high, with only 3.75 teleoconch whorls: BENTHEDI, stn DS72) differs from T. polycyma in having a broader teleoconch whorl, a broader aperture with a wide, flared, columellar lip and a narrower, abapically tapered siphonal canal. Typical specimens from T. polycyma have been examined since then from Japan and from Fiji (Houart \& Héros 2008).

\section{Genus Flexopteron Shuto, 1969}

TYPE SPECIES. - Flexopteron philippinensis Shuto, 1969, Late Miocene, Philippines (by original designation).

\section{REMARKS}

There are currently two known Recent species of Flexopteron: F. primanova (Houart, 1985) from Madagascar and F. poppei (Houart, 1993) from the Philippines. Two other Recent species were included in Flexopteron by Merle et al. (2011): Poirieria (Paziella) tanaoa Houart \& Tröndlé, 2008 from the Marquesas and Paziella (Flexopteron) sp. from the Philippines. Paziella (Flexopteron) sp. (Merle et al. 2011: pl. 141, figs 12a, b) is a species of Coralliophilinae, probably in the genus Lamellatiaxis Habe \& Kosuge, 1970.
We do not accept the classification of Poirieria (Paziella) tanaoa in Flexopteron by Merle et al. (2011). The radula characters are not known for $P$. tanaoa but its shell is quite different from that of species of Flexopteron, being more elongate with fewer spiral cords, a relatively smaller aperture and a longer siphonal canal, shell characters that are closer to Paziella than to Flexopteron. In fact, $P$. tanaoa strongly resembles the specimen illustrated by Merle et al. (2011: pl. 144, figs 4a, b) as Crassimurex (Eopaziella) capita (Philippi, 1844) from the Late Oligocene of Europe. Currently we do not see any reason to remove $P$. tanaoa from Paziella.

The shell morphology of Flexopteron akainakares n. sp. is close to F.primanova Houart, 1985 but the species has different radula characters and is here only tentatively assigned to this genus.

We have now used Flexopteron as a full genus since its radular morphology (Fig. 14D-F) is different from Poirieria (Marshall \& Houart, 1995).

Flexopteron akainakares $\mathrm{n}$. sp.

(Figs 2D, E; 6P, Q; 8A-E; 9B; 14B, C)

Type MATERial. - Holotype (dd) MNHN-IM-2000-30012 and 4 paratypes MNHN, 1 paratype coll. RH (as listed below). 


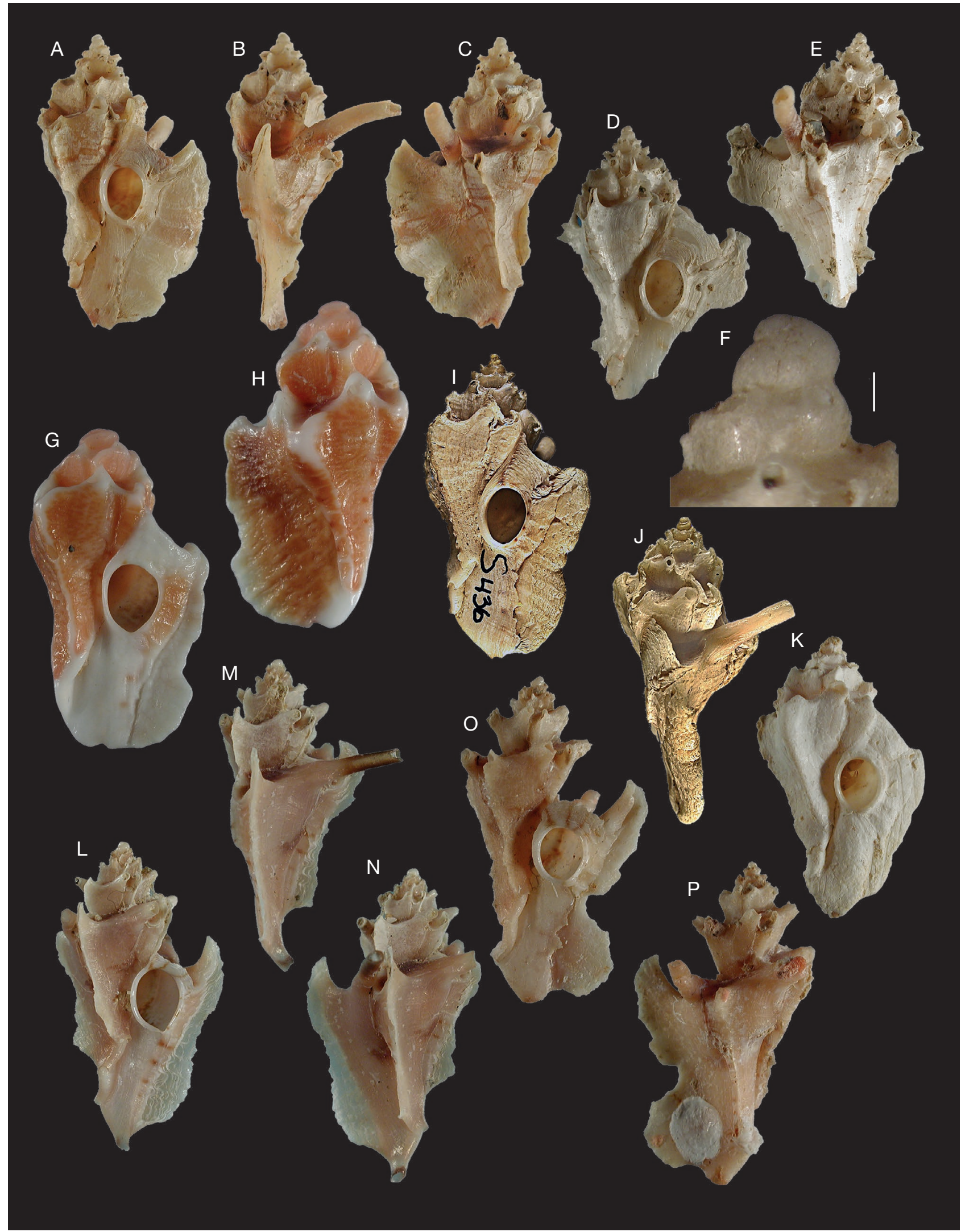

FIG. 10. - A-F, Typhinellus laminatus n. sp.; MIRIKY, stn DW3245, 90-257 m; A-C, holotype MNHN IM-2000-30019, 16.3 mm; D, E, paratype MNHN IM-200030020, 14.8 mm; F, protoconch; G, H, Typhinellus bicolor Bozzetti, 2007; South Madagascar, Lavanono, holotype MNHN IM-2000-20852, 21.2 mm; I, J TyphinelIus amoenus (Houart, 1994), Umhlanga Rocks, Natal, South Africa, holotype NMSA S436, 21 mm, photo courtesy A. Marais; K, Typhinellus androyensis Bozzetti, 2007; ATIMO VATAE, BB04, 14-18 m, 14.9 mm; L-P, Typhinellus constrictus n. sp.: L-N, ATIMO VATAE, BS09, 11-13 m, holotype MNHN IM-2009-14446, 15.4 mm; O, P, ATIMO VATAE, stn CP3511, 97-98 m, paratype MNHN IM-2000-30022 $20.7 \mathrm{~mm}$. Scale bar: F, $500 \mu \mathrm{m}$. 


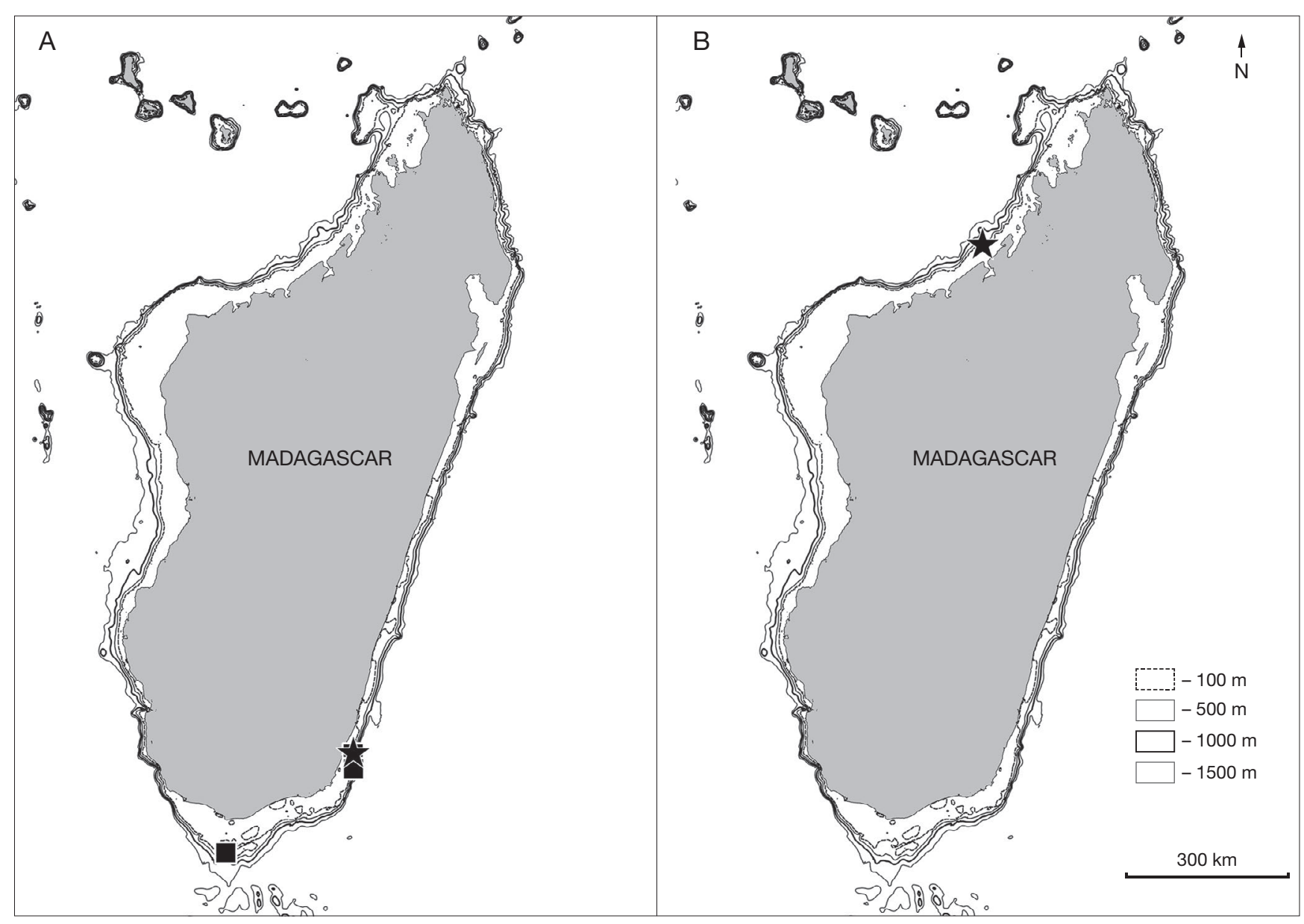

FIG. 11. - Distributions of: A, Murexsul mananteninaensis n. sp.; B, Typhinellus laminatus n. sp. Symbols: $\star$, type locality; $\mathbf{\square}$, other occurences.

TYPE LOCALITY. - South Madagascar, Manantenina sector, 24²3’' 47³2'E, 307-319 m [ATIMO VATAE: stn DW3524].

Material EXAMINED. - South Madagascar. ATIMO VATAE: stn DW3515, between Lokaro and Sainte Luce, $24^{\circ} 53^{\prime} \mathrm{S}, 47^{\circ} 28^{\prime} \mathrm{E}$, 184-203 m, 1 lv, 2 dd (paratypes MNHN-IM-2000-30013). - Stn DW3524, Manantenina sector, $24^{\circ} 23^{\prime} \mathrm{S}, 47^{\circ} 32^{\prime} \mathrm{E}, 307-319 \mathrm{~m}, 1 \mathrm{dd}$ (holotype MNHN-IM-2000-30012), 3 dd, juv. - Stn DW3528, Manantenina sector, $24^{\circ} 24^{\prime} \mathrm{S}, 47^{\circ} 33^{\prime} \mathrm{E}, 424-438 \mathrm{~m}, 13 \mathrm{dd}$ (1 paratype Coll. RH). - Stn DW3529, Manantenina sector, 242 $24^{\prime}$ S, $47^{\circ} 33^{\prime} \mathrm{E}$, 402-407 m, 1 dd (paratype MNHN-IM-2000-30014). - Stn DW3534, Sainte Luce sector, 2443'S, 47³2'E, 296-307 m, 2 dd, juv.

Distribution. - South Madagascar, taken alive at 184-203 m, shells at 203-424 m.

EтYMOLOGY. - Greek, akaina, spine and akares, short, small. This species is named for the small and short spines on the axial lamellae.

\section{DESCRIPTION}

Shell medium sized for the subgenus, up to $12.2 \mathrm{~mm}$ in height at maturity. Height/width ratio 1.5-1.7. Broadly ovate, weakly spinose, lightly built. Subsutural ramp narrow, weakly sloping on spire whorls, broader, strongly sloping on last teleoconch whorl, weakly concave. Shell entirely white.

Spire high with 1.5 protoconch whorls and up to 4.15 broad, convex, angular, strongly shouldered, weakly spinose whorls.
Suture impressed. Protoconch large, broad, whorls rounded, smooth, maximum width 900-1000 $\mu \mathrm{m}$. Terminal lip weakly raised, narrow, prosocline.

Axial sculpture of teleoconch whorls consisting of low, narrow, weakly webbed lamellae, more strongly developed at shoulder, producing short, narrow, broadly open spines at intersection of lamellae and primary spiral cords. First whorl with 6 or 7 lamellae, second with 7 or 8 , third 7-9, fourth 6-9, last (apertural) with 6-7. Spiral sculpture of high, rounded, narrow, weakly squamous, primary cords, low, narrow secondary cords and numerous, narrow, low threads. First teleoconch whorl with P1 and P2, broadly separated by a large gap, second whorl with P1 and P2, starting weak s1 and one or two threads, third whorl with P1 and P2, weak s1 and narrow, weak threads of various strength, fourth and last whorls with P1, s1, P2, P3, P4, (s4), P5, (s5), P6, s6, adp and several threads of different magnitude.

Aperture small, ovate. Columellar lip broad, flaring, smooth or occasionally with one or two weak knobs abapically, rim partially erect, adherent at adapical extremity. Occasionally with weak, very low parietal tooth at adapical extremity. Anal notch shallow, broad. Outer lip weakly erect, smooth with four weak or moderately strong, broad denticles within: D1, D2, D3, D4-D5 fused. Siphonal canal short, broad, weakly dorsally recurved, broadly open. 
Operculum ovate, light brown with apical nucleus.

Radula (Fig. 14B, C) muricine with broad rachidian bearing long, narrow, central cusp; short, triangular lateral denticles, almost half the size of central cusp; broad, long, triangular lateral cusps. Marginal area short, occasionally with small marginal denticle, almost indistinct when present. Marginal cusp short, outwardly bent.

Lateral teeth sickle shaped, long, with broad base.

\section{REMARKS}

Flexopteron akainakares n. sp. differs in many ways from F. poppei and does not need to be compared here.

Flexopteron primanova (Fig. 8F-I) was described from northern Madagascar but $F$. akainakares n. sp. is not sympatric, living more to the South. Flexopteron akainakares n. sp. differs in having a relatively smaller shell, a higher and larger protoconch (900-1000 wide and $900 \mu \mathrm{m}$ high vs 850900 wide and $700-800 \mu \mathrm{m}$ high) with rounded first whorl vs flat in F. primanova, markedly shorter shoulder spines on the last teleoconch whorl in adult specimens, a shorter siphonal canal, a different morphology of the primary spiral cords of the teleoconch whorls, and a last teleoconch whorl with $\mathrm{P} 1$, s1, P2, P3, P4, (s4), P5, (s5) and P6, with a broad gap between P1 and P2 as opposed to P1, P2, (s2), P3, P4, P5, (P6).

The radula of $F$. primanova (Fig. $14 \mathrm{D}-\mathrm{F}$ ) is also different in having a very long, narrow central cusp, narrow lateral denticles approximately half the size of the central cusp, long, narrow, lateral cusps even longer than the central cusp, a smooth marginal area and acute, moderately long, marginal cusps.

The operculum is similar, being ovate with an apical nucleus.

\section{Genus Murexsul Iredale, 1915}

Type SPECIES. - Murex octogonus Quoy \& Gaimard, 1832, New Zealand (by original designation).

\section{Murexsul mananteninaensis $\mathrm{n} . \mathrm{sp}$.}

Figs 2C; 8J-N; 11A

TyPe MATERIAL. - Holotype (lv) MNHN-IM-2000-30015 and 3 paratypes MNHN, 1 paratype coll. RH (as listed below).

TYPE LOCALITY. - South Madagascar, Manantenina sector, $24^{\circ} 23^{\prime} \mathrm{S}$, 47³2'E, 307-319 m [ATIMO VATAE: stn DW3524].

MATERIAL EXAMINED. - South Madagascar. ATIMO VATAE: stn DW3523, Manantenina sector, $24^{\circ} 23^{\prime} \mathrm{S}, 4^{\circ} 31^{\prime} \mathrm{E}, 200-220 \mathrm{~m}, 2 \mathrm{dd}$ (1 paratype MNHN-IM-2000-30016, 1 paratype Coll. RH). — Stn

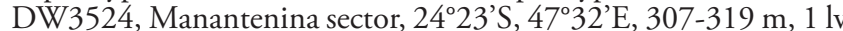
(holotype MNHN-IM-2000-30015), 1 dd (paratype MNHNIM-2000-30017). - Stn DW3532, North of Sainte Luce, 2439.4'S, 4731.7’E, 86-87 m, 1 lv (paratype MNHN-IM-2000-30018). - Stn

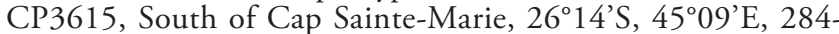
$286 \mathrm{~m}, 1 \mathrm{dd}$.

DisTRibution. - Southern Madagascar, taken alive at 87-307 m, shells at $220-307 \mathrm{~m}$.

ETyMOLogy. - Named after the type locality.

\section{DESCRIPTION}

Shell very small for the genus, up to $5.3 \mathrm{~mm}$ in height at maturity. Height/width ratio 1.9 (holotype). Slender, lanceolate, biconical, narrow, very weakly spinose, lightly built. Substural ramp narrow, weakly sloping, very slightly convex. Entirely white, translucent white or orange (paratype MNHN).

Spire high with 1.5 protoconch whorls and teleoconch of three broadly-convex, elongate, weakly shouldered whorls. Suture impressed. Protoconch large, broad, whorls rounded, smooth, maximum width $600 \mu \mathrm{m}$. Terminal lip delicate, narrow, weakly erect, very weakly curved.

Axial sculpture of teleoconch whorls consisting of very low, weak, quite indistinguishable, narrow, lamellose ribs and low, weak, narrow varices. First whorl with eight or nine ribs, second and third with ribs and varices of same strength as each other. Apertural varix high, broad, rounded with five very short, blunt, broadly open spinelets, extending from P1-P5. Spiral sculpture of low, rounded, narrow primary and secondary cords. First teleoconch whorl starting with P3 only, starting P1 and P2 at the end of the whorl, second whorl with P1-P3, occasionally with P4 almost entirely covered by following whorl, last whorl with P1, s1, P2, (s2), P3, P4, s4, P5, s5, P6, ADP, (MP). P1-P5 almost similar in strength and height, P6 narrower.

Aperture moderately large, ovate. Columellar lip narrow, strongly flaring, smooth, rim partially erect, adherent at adapical extremity. Anal notch shallow, broad. Outer lip erect, smooth within. Siphonal canal moderately long, narrow, weakly dorsally recurved, open.

Operculum and radula not examined.

\section{REMARKS}

Murexsul mananteninaensis n. sp. is part of a small group of species with only three or four teleoconch whorls but that seem to have reached adult size: Murexsul asper Houart, 2004 from Western Australia, M. queenslandicus n. sp. Houart, 2004 from Queensland, Australia, M. leonardi (Houart, 1993) from Christmas Island, M. charcoti (Houart, 1991) and M. micra (Houart, 2001) from New Caledonia. Many specimens have been examined from Australia and New Caledonia and none of these reaches a height of more than $7.5 \mathrm{~mm}$.

Compared to $M$. mananteninaensis n. sp., $M$. asper has a larger shell, reaching $8.6 \mathrm{~mm}$ in height, with broader spiral cords and higher IP and abis.

Murexsul queenslandicus (Fig. 8O, P) is broader and heavier with broader spiral cords, no secondary spiral cords and a broader, higher apertural varix.

Murexsul leonardi differs markedly and does not need to be compared here.

Murexsul charcoti (Fig. 8Q, R) is larger, reaching a height of $7.2 \mathrm{~mm}$, and broader with broader, more obvious axial varices, broader spiral cords and small, blunt spinelets on axial varices and on the siphonal canal.

Murexsul micra (Fig. 8S) is smaller, reaching a height of $3.9 \mathrm{~mm}$, with a lower spire, broader spiral cords, more obvious axial varices with short, blunt spinelets and a smaller aperture. 
Curiously, Murexsul mananteninaensis n. sp. also resembles species of Enatimene Iredale, 1929, a genus confined to eastern Australia, comprising three species. The shell morphology of E. lanceolatus Houart, 2004 is particularly close to Murexsul mananteninaensis n. sp., but E. lanceolatus is twice as large for the same number of teleoconch whorls, has a rounded protoconch and a first teleoconch whorl with P1-P3. The genus Enatimene is currently classified in Trophoninae s.l. Cossmann, 1903 and its radula characters are distinct from those of the Muricopsinae Radwin \& D’Attilio, 1971.

\section{Genus Typhinellus Jousseaume, 1880.}

TyPE SPECIES. - Typhis sowerbyi Broderip, 1833 (= Murex labiatus Cristofori \& Jan, 1832), Mediterranean, eastern Atlantic (by original designation).

\section{Typhinellus laminatus n. sp.} (Figs 10A-F; 11B)

TYPE MATERIAL. - Holotype (lv) MNHN-IM-2000-30019 and 1 (dd) paratype MNHN-IM-2000-30020.

Type LOCALiTy. - Madagascar, off Baie Mahajamba, 14²53'S, 46 $56^{\circ}$ E, 90-257 m [MIRIKY: stn DW3245].

Material eXamined. - Only known from the type material.

Distribution. - North-western Madagascar, taken alive at 90-257 m.

Etymology. - Latin, lamina, thin blade. This species is named for its thin axial lamellae.

\section{DESCRIPTION}

Holotype medium sized for the genus, $16.3 \mathrm{~mm}$ in height. Height/width ratio 1.7, narrowly-ovate, smooth, delicate. Subsutural ramp moderately broad, weakly sloping, weakly concave.

Light ochre or light tan, brown on subsutural ramp on third, fourth and last teleoconch whorls, light brown spiral band at periphery. A single brown spot at adapical edge of aperture and three on edge of outer apertural lip. Three additional weak, light brown spots on left part of ventral side of siphonal canal.

Spire high with 1.75 protoconch whorls and five weakly convex, angulate, strongly shouldered teleoconch whorls. Suture of whorls impressed. Protoconch small, whorls rounded, slightly eroded. Terminal lip unknown (eroded).

Axial sculpture of teleoconch whorls consisting of four high, thin, sharp lamellate varices, each with a weakly open, short, inward curved shoulder spine. Apertural varix broad, flangelike, dorsally reflected, with two broadly open, short spinelets at outer edge. Variceal flange extending to tip of siphonal canal. Shoulder spine broad, triangular, very weakly dorsally curved, connected to last teleoconch whorl by a broad, high, lamellate partition. Spiral sculpture faint, consisting of P1 with the anal tube, P2 (shoulder spine) and probably P3, P4, P5 and P6 with very faint secondary cords. Spiral sculpture more obvious on adapertural part of apertural varix. P1 with long, tapering, ventrally sealed anal tube, forming an angle of approximately $85-90^{\circ}$ with axis of shell, only apertural tube hollow and functional, older tubes broken off and closed. P2 with a weakly open, curved shoulder spine, P4 and P5 corresponding to broad, open spinelets at outer apertural margin. Very thin intritacalx consisting of simple axial striae present.

Aperture small, ovate, forming a continuous peristome. Columellar lip narrow, outer lip smooth within. Siphonal canal long, broad, straight, ventrally sealed. Left side of canal weakly overlapping right side.

Operculum and radula unknown.

\section{REMARKS}

Typhinellus laminatus n. sp. differs from Typhinellus bicolor Bozzetti, 2007 (Fig. 10G, H) in having a smooth shell with the exception of a few, rather indistinct spiral cords, whereas T. bicolor has a microsculpture of irregular pits, visible even in the worn holotype. Typhinellus laminatus n. sp. also has a more fragile shell, sharper axial varices and a slightly smaller aperture, $17.1 \%$ of shell height and $19 \%$ of shell width as opposed to $17.6 \%$ of shell height and $22.6 \%$ of shell width in T. bicolor (measurements made on the holotype of T. laminatus $\mathrm{n}$. sp. and specimens of T. bicolor from ATIMO VATAE, stn BP11).

Typhinellus laminatus n. sp. differs from T. androyensis Bozzetti, 2007 (Fig. 10K) in having a more fragile shell with narrower teleoconch whorls, much thinner and sharper axial varices and a flatter siphonal canal.

Typhinellus laminatus $\mathrm{n}$. sp. differs from T. amoenus Houart, 1994 (Fig. 10I, J) in the same characters as it differs from T. androyensis but also in having a smooth shell as opposed to the strongly spirally sculptured shell in T. amoenus.

\section{Typhinellus constrictus $\mathrm{n}$. sp.}

(Figs 10L-P; 13A)

TyPe MATERIAL. - Holotype (lv) MNHN-IM-2009-14446 and 5 paratypes MNHN; 1 paratype coll. RH (as listed below).

TYPE LOCALITY. - Madagascar, sector of Fort-Dauphin, $25^{\circ} 15.0^{\prime} \mathrm{S}$, 47²14.5’E, 97-98 m. [ATIMO VATAE: stn BS09].

Material EXAMINED. - South Madagascar. ATIMO VATAE:

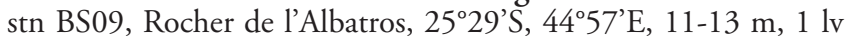
(holotype MNHN-IM-2009-14446). - Stn BP22, West sector

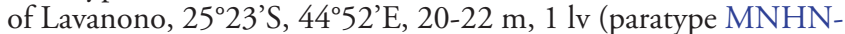
IM-2009-22522 BOLD ID BOMGA027-15, GenBank accession number KP697991 for COI gene KC860506). - Stn BP42,

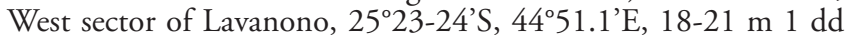
(paratype MNHN-IM-2000-30021). - Stn CP3511, sector of Fort-Dauphin, $25^{\circ} 15^{\prime} \mathrm{S}, 47^{\circ} 15^{\prime} \mathrm{E}, 97-98 \mathrm{~m}, 1 \mathrm{dd}$ (paratype MNHN-

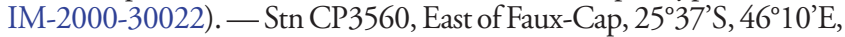
102-106 m, 2 dd (2 paratypes MNHN-IM-2000-30023). - Stn

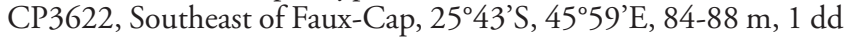
(paratype Coll. RH). - No data, South Madagascar, sector of Fort Dauphin, 1 dd (MNHN).

DisTRibution. - South Madagascar, taken alive at 13-20 m, empty shells at 21-102 m. 


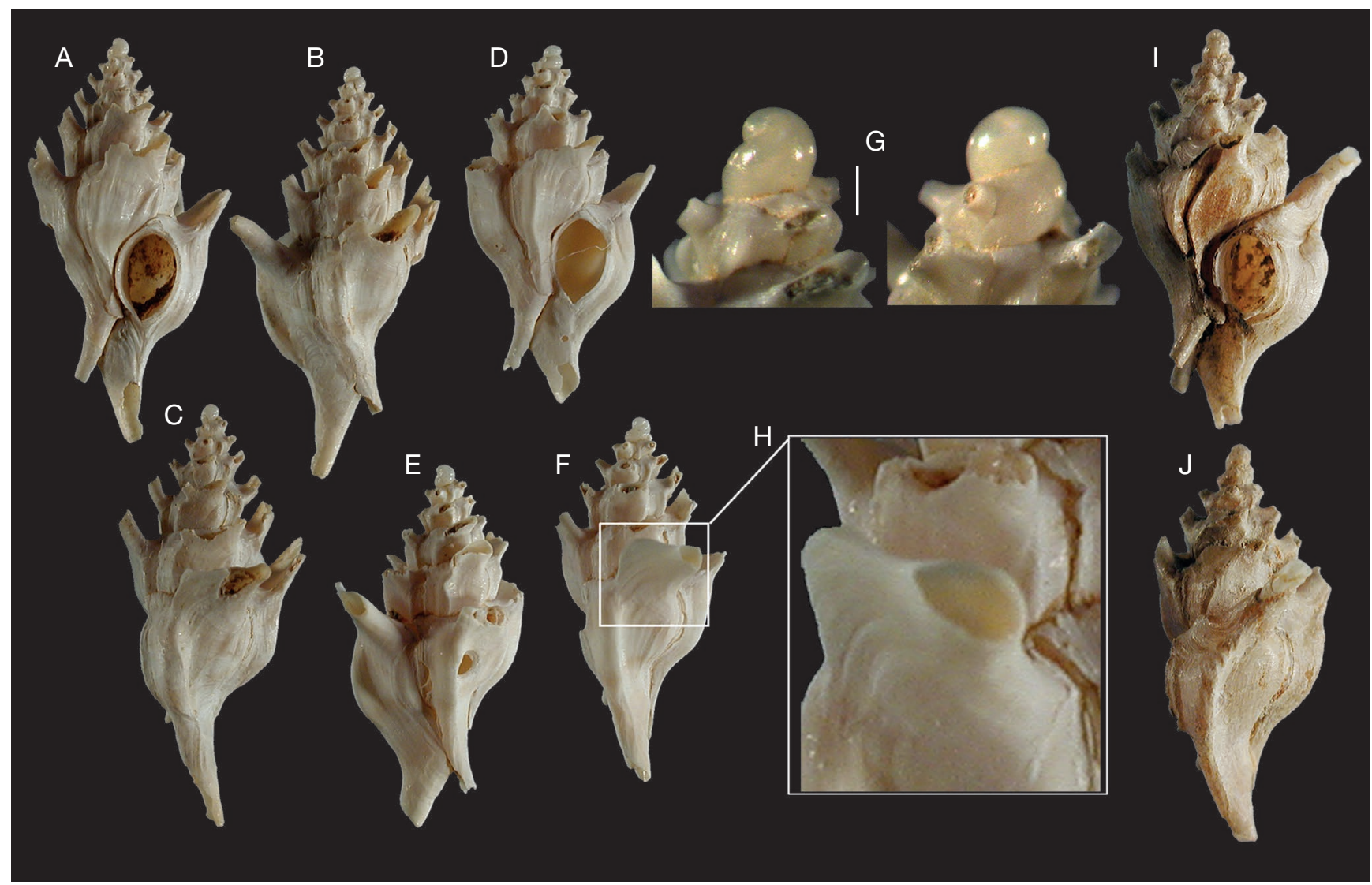

FIG. 12. - A-H, Siphonochelus (Siphonochelus) aethomorpha n. sp.; MIRIKY, stn DW3259, 177-199 m: A-C, holotype MNHN IM-2000-30024, 11.6 mm; D-F, paratype MNHN IM-2000-30025; 9.0 mm; G, protoconch; H, detail of the anal tube; I, J, Siphonochelus (Siphonochelus) arcuatus (Hinds, 1843); ATIMO VATAE, stn CP3584, 203-210 m, $11.5 \mathrm{~mm}$. Scale bar: $500 \mu \mathrm{m}$.

ETYMOLOGY. - Latin, constrictus, constricted. This species is named for the peculiar form of the teleoconch whorl.

\section{DESCRIPTION}

Shell large for the genus, up to $20.7 \mathrm{~mm}$ in height at maturity (holotype), although one incomplete paratype (MNHN) would have been larger. Height/width ratio 1.73 (holotype). Slender, narrowly ovate with expanded shoulder, lightly built. Subsutural ramp broad, almost horizontal, weakly convex.

Tan or light brown, subsutural ramp darker. Abapertural side of apertural flange and ventral part of siphonal canal beige or light tan. Three or four axial, narrow, brown bands on partition. Aperture white.

Spire high with paucispiral, weakly shouldered protoconch (observed in one specimen but partly broken). Teleoconch up to five angulate, strongly shouldered whorls. Abapical part of whorls constricted. Suture impressed.

Axial sculpture of teleoconch whorls consisting of four, low, thin, sharp lamellate varices, each with a weakly open, inward curved shoulder spine. Apertural varix thin, broad, constricted medially, broader at abapical extremity, extending from shoulder spine almost to tip of siphonal canal. Apertural shoulder spine adapically bent, long, narrowly triangular, straight, connected to last teleoconch whorl by a broad, thin, lamellate partition. Partition with two or three backward bent, short, flattened, broad spinelets. Spiral sculpture very faint, consisting of P1 with the anal tube, P2 (shoulder), P3, P4 and P5 only discernable on variceal flange and only very weakly between axial varices, corresponding to the broad, weakly curved abapertural spinelets at outer apertural margin. P1 with long, rounded, ventrally sealed anal tube, forming an angle of approximately $85-90^{\circ}$ with axis of shell. Only apertural tube hollow and functional, older tubes broken off and closed. Two narrow spiral cords between abapical part of aperture and variceal flange, occasionally obvious in some shells. Other sculpture of few, weak and very thin, low, broad scales, only visible on last teleoconch whorl, between axial varices.

Aperture small, rounded, erect, forming a continuous peristome. Columellar lip narrow, outer lip smooth within. Siphonal canal long, broad, straight, ventrally sealed, dorsally bent at tip. Left side of canal weakly overlapping right side.

Operculum and radula unknown.

\section{REMARKS}

Typhinellus constrictus $\mathrm{n}$. sp. differs from all the other Typhinellus species in having a broad, almost straight shoulder ramp, deeply constricted teleoconch whorls with an impressed suture and a rounded aperture. 


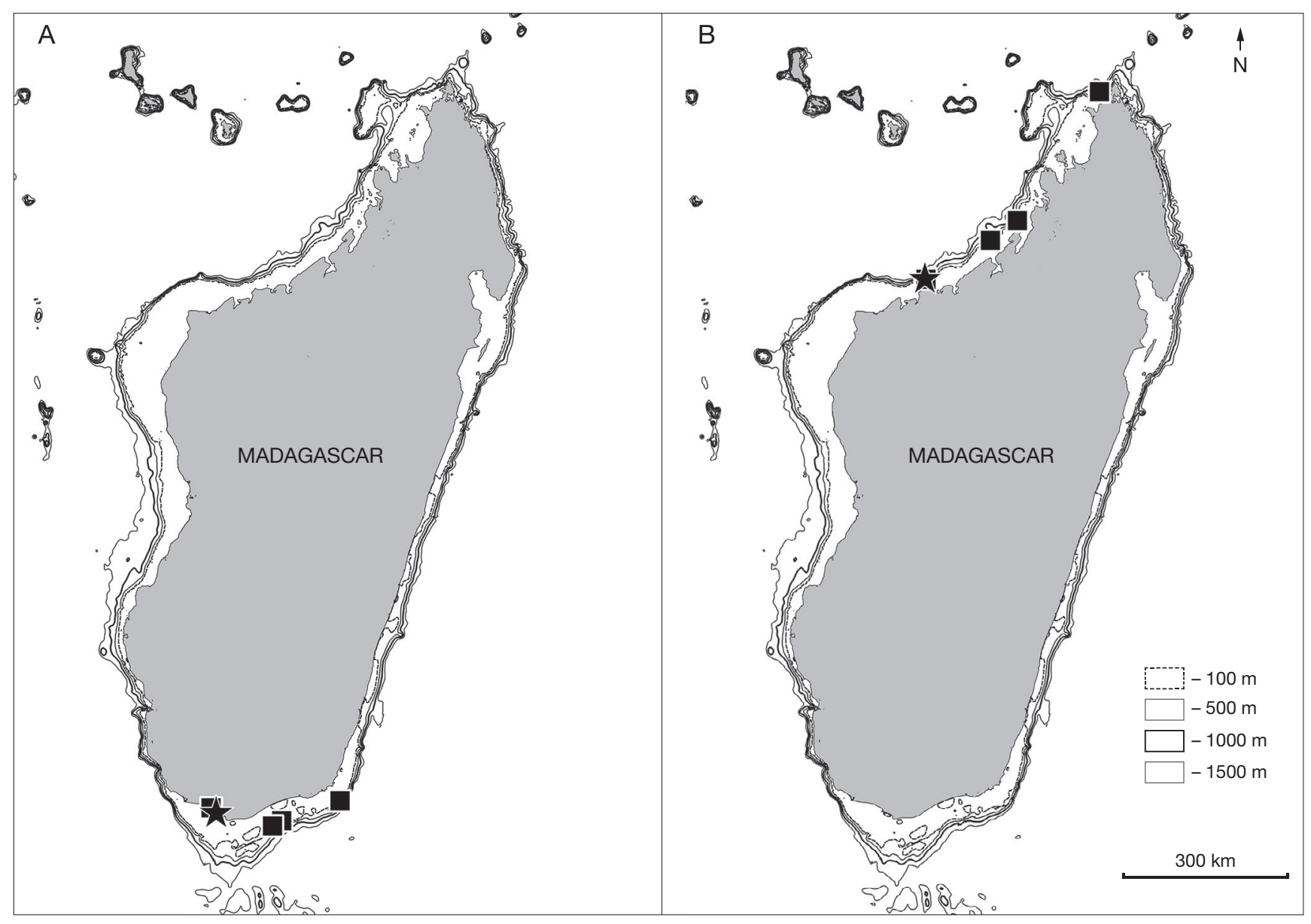

FIG. 13. - Distributions of: A, Typhinellus constrictus n. sp.; B, Siphonochelus (Siphonochelus) aethomorpha n. sp. Symbols: , type locality;

other occurences.

Genus Siphonochelus Jousseaume, 1880

Subgenus Siphonochelus Jousseaume, 1880

TyPe SPECIES. - Typhis arcuatus Hinds, 1843, South Africa (by original designation).

\section{Siphonochelus (Siphonochelus) aethomorpha n. sp.} (Figs 12A-H; 13B)

Type MATERIAL. - Holotype MNHN-IM-2000-30024, 10 paratypes MNHN-IM-2000-30025, 2 paratypes Coll. RH.

Type LOCALITY. - Madagascar, between Majunga and Cap SaintAndré, $15^{\circ} 35^{\prime} \mathrm{S}, 45^{\circ} 43^{\prime} \mathrm{E}, 177-199$ m [ATIMO VATAE: stn DW3259].

MATERIAL EXAMINED. — South Madagascar. MIRIKY: stn DW3197, West of Cap d'Ambre, $12^{\circ} 07^{\prime} \mathrm{S}, 48^{\circ} 58^{\prime} \mathrm{E}, 362-431 \mathrm{~m}, 3 \mathrm{dd}$, juv. - Stn DW3239, in front of Baie de Nazendry, $14^{\circ} 30^{\prime} \mathrm{S}, 47^{\circ} 26^{\prime} \mathrm{E}, 230$ $288 \mathrm{~m}, 1 \mathrm{dd}$, juv. - Stn CP3241, in front of Baie de Nazendry, $14^{\circ} 30^{\prime} S$, $47^{\circ} 27^{\prime} \mathrm{E}$, 274-325 m, 1 dd, juv. - Stn DW3258, between Majunga and Cap Saint-André, 1534'S, 45 44'E, 200-288 m, 7 dd, juv. - Stn DW3259, between Majunga and Cap Saint-André, $15^{\circ} 35^{\prime} \mathrm{S}, 45^{\circ} 43^{\prime} \mathrm{E}, 177-199 \mathrm{~m}, 30 \mathrm{dd}$, ad \& juv (holotype MNHNIM-2000-30024, 10 paratypes MNHN-IM-2000-30025, 2 paratypes Coll. RH). - Stn CP3260, between Majunga and Cap Saint-André, $15^{\circ} 35^{\prime} \mathrm{S}, 45^{\circ} 45^{\prime} \mathrm{E}, 179-193 \mathrm{~m}, 1 \mathrm{dd}$, juv. - Stn CP3283, off Baie Mahajamba, $14^{\circ} 52^{\prime}$ S, $46^{\circ} 56^{\prime} \mathrm{E}, 228-257 \mathrm{~m}, 5 \mathrm{dd}$, juv.
Distribution. - North-western Madagascar, 193-362 m (shells only).

ETYMOLOGY. - Greek, morpho, form, shape and aethes, unusual, strange. This species is named for the strange and flattened form of the anal tubes.

\section{DESCRIPTION}

Shell medium sized for the subgenus, up to $11.1 \mathrm{~mm}$ in height at maturity (holotype). Height/width ratio 1.9-2.1. Slender, lanceolate, narrowly ovate, lightly built. Subsutural ramp narrow, weakly sloping, weakly concave. Shell entirely off white.

Spire high with 1.25-1.5 protoconch whorls and up to 5-5.25 weakly convex, weakly shouldered, smooth whorls. Suture impressed. Protoconch moderately large, narrow, slightly elongate. Whorls rounded, smooth, maximum width $600 \mu \mathrm{m}$. Terminal lip delicate, thin, curved.

Axial sculpture consisting of four, low, narrow, rounded, weakly shouldered varices from first to last whorl. Spiral sculpture of very shallow P1 with anal tube, P2 (shoulder) and very weak, narrow striae and lirae, occasionally extending on abapical part of anal tubes. Anal tubes rounded on first or first two teleoconch whorls, flattened from second or third whorl. Last whorl with very broad, very flattened tubes originating from succeeding varix, filling almost entire space between succeeding and pre- 

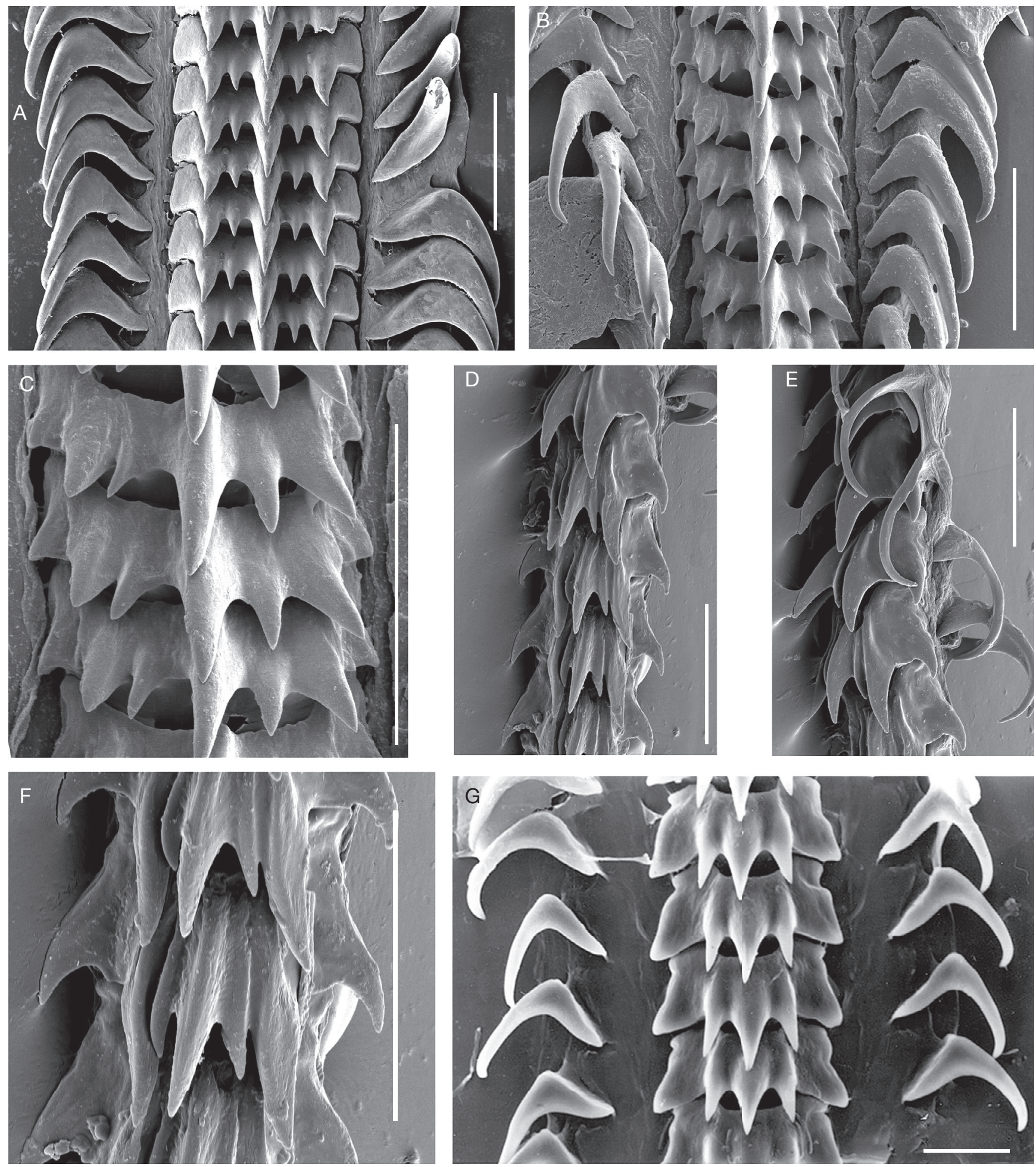

FIG.14. - Radulae: A, Vokesimurex rectaspira n. sp.; ATIMO VATAE, stn CP3589, paratype MNHN IM-2000-30001; B, C, Flexopteron akainakares n. sp.; ATIMO VATAE, stn DW3515, paratype MNHN IM-2000-30013; D-F, Flexopteron primanova (Houart, 1985); MIRIKY, stn CP3210, scale bar 25 um; G, Bouchetia vaubanensis (Houart, 1986); New Caledonia, BIOCAL, stn DW44. Scale bars: A, $100 \mu \mathrm{m}$; B, C, $20 \mu \mathrm{m}, \mathrm{D}-\mathrm{F}, 25 \mu \mathrm{m} ; \mathrm{G}, 10 \mu \mathrm{m}$.

ceding varix, forming an angle of approximately $30-40^{\circ}$ with axis of shell. Last apertural anal tube strongly outward bent, forming an angle of approximately $70^{\circ}$ with axis of shell. Only apertural tube hollow and functional, older tubes broken off and closed. Only small portion of last tube open (Fig. 12H).
Aperture moderately small, ovate, weakly erect, forming a continuous peristome. Columellar lip narrow, smooth. Outer lip smooth within. Siphonal canal moderately long, narrow, straight, ventrally sealed, weakly dorsally curved, strongly tapered abapically. 


\section{REMARKS}

Siphonochelus aethomorpha n. sp. differs from all the other Siphonochelus species in having very broad and flat anal tubes that originate from the succeeding varix and fill almost all the space between the succeeding and the preceding varix. The five other species occurring in Madagascar, Mozambique and/or southern Africa, i.e. S. (S.) arcuatus (Hinds, 1843), S. (S.) pentaphasios (Barnard, 1959), S. (S.) rosadoi Houart, 1999, S. (S.) stillacandidus Houart, 1985 and S. (S.) transcurrens (Martens, 1903), differ markedly, as do the other IndoWest Pacific species.

Siphonochelus arcuatus (Fig. 12I, J) has broader teleoconch whorls with sharper axial varices, more strongly backwardly bent, less flattened anal tubes and an almost three times larger protoconch.

Siphonochelus pentaphasios differs in the same characters and in having teleoconch whorls with five varices per whorl instead of four.

Siphonochelus stillacandidus also differs in having much narrower anal tubes, slightly more distant from the more strongly shouldered axial varices, and in having a shorter siphonal canal.

The two other Indian Ocean species differ in many shell characters and do not need to be compared here.

\section{Acknowledgements}

The ATIMO VATAE and MIRIKY expeditions to Madagascar (Principal Investigator, Philippe Bouchet) was part of a cluster of Mozambique-Madagascar expeditions funded by the Total Foundation, Prince Albert II of Monaco Foundation, and Stavros Niarchos Foundation under "Our Planet Reviewed", a joint initiative of MNHN and Pro Natura International (PNI) in partnership with Institut d'Halieutique et des Sciences Marines, University of Toliara (IH.SM) and the Madagascar bureau of Wildlife Conservation Society (WCS).

We are grateful to Philippe Bouchet for his continuous help in many ways during the finalizing of this paper; to Robert H. Cowie (University of Hawaii, USA) for his useful and appreciated comments on the manuscript; to Alwyn Marais (Centre for Molluscan Studies, Groenkloof, South Africa) for the image of Typhinellus amoenus (holotype); to Marco Oliverio (University La Sapienza, Rome, Italy) for his remarks on the molecular specimens and to Anders Warén (Natural History Museum, Stockholm, Sweden) for preparation of, and SEM work on the radulae. The molecular sequences were obtained by Céline Bonillo and José Utge in the Service de Systématique Moléculaire of the MNHN, and we also thank Nicolas Puillandre, Barbara Buge and Philippe Maestrati (MNHN). Gilberto Marani (MNHN) prepared the distribution maps, and Manuel Caballer (MNHN) provided the images of the MNHN types, E-Recolnat Project: ANR-11-INBS-0004. Thanks also to the two reviewers, Marco Oliverio and Bruce Marshall (Te Papa Tongarewa, Museum of New Zealand) for their useful remarks.

\section{REFERENCES}

Barco A., Claremont M., Reid D. G., Houart R., Bouchet P., Williams S. T., Cruaud C., Couloux A. \& Oliverio M. 2010. - A molecular phylogenetic framework for the Muricidae, a diverse family of carnivorous gastropods. Molecular Phylogenetics and Evolution 56: 1025-1039.

BoucheT P. 1999. - A new Lyria (Gastropoda, Volutidae) from southeastern Madagascar. The Nautilus 113 (1): 1-3.

BozzetTI L. 2001. - Chicoreus monicae sp. n. (Gastropoda, Muricidae) dal Madagascar Meridionale. Malacologia Mostra Mondiale 34: 9-10.

BozzeTTi L. 2006. - Vitularia minima (Gastropoda: Hypsogastropoda: Muricidae: Thaidinae) nuova specie dal Madagascar Meridionale. Malacologia Mostra Mondiale 53: 9-10.

BozZeTTI L. 2011. - Chicoreus felicitatis (Gastropoda: Hypsogastropoda: Muricidae: Muricinae) nuova specie dal Madagascar Sud-Orientale. Malacologia Mostra Mondiale 70: 10-12.

Cecalupo A. \& Perugia I. 2014. - The Cerithiopsidae (Caenogastropoda: Triphoroidea) of South Madagascar (Indian Ocean). Bollettino Malacologico 50: 75-126

GREGORIO A. DE, 1885. — Studi su talune conchiglie mediterranee viventi e fossili con una rivista del gen. Vulsella e del gen. Ficula. Bulletin de la Società Malacalogico Italiana 10: 36-288.

HouART R. 1985. - Report on Muricidae (Gastropoda) recently dredged in the Southern-Western Indian Ocean - II. List of species with remarks and illustrations. Venus 44 (4): 239-248.

HOUART R. 1991 — Description of thirteen new species of Muricidae (Gastropoda) from Australia and the New Caledonian region, with range extensions to South Africa. Journal of the Malacological Society of Australia 12: 35-55.

HouArT R. \& Héros V. 2008. - Muricidae (Mollusca: Gastropoda) from Fiji and Tonga, in Héros V, Cowie R. H. \& Bouchet P. (eds), Tropical Deep-Sea Benthos 25. Mémoires du Muséum national d'Histoire naturelle 196: 437-480.

Houart R. \& Héros V. 2013. — Description of new Muricidae (Mollusca: Gastropoda) collected during the ATIMO VATAE expedition to Madagascar "Deep South". Zoosystema 35 (4): 503-523, http://dx.doi.org/10.5252/z2013n4a5

IREDALE T. 1915. - A commentary on Suter's "Manual of New Zealand Mollusca". Transactions and Proceedings of the New Zealand Institute 47: 417-497.

Jousseaume F. 1880. - Division méthodique de la famille des purpuridés. Le Naturaliste 2 (442): 335-336.

KoOL S. P. 1993. - Phylogenetic analysis of the Rapaninae (Neogastropoda: Muricidae). Malacologia 35 (2): 155-259.

Kuroda T. 1953. - New genera and species of Japanese Gastropoda (1). Venus 17: 179-185.

Lutjeharms J. R. E. \& MACHU E. 2000. - An upwelling cell inshore of the East Madagascar Current. Deep-Sea Research I 47: 2405-2411

Marshall B. A. \& Houart R. 1995. - A review of the New Zealand Recent species of Poirieria Jousseaume, 1880 (Mollusca: Gastropoda: Muricidae) with description of a new species. Nautilus 118 (2): 27-33.

MERLE D. 2001. - The spiral cords and the internal denticles of the outer lip in the Muricidae: terminology and methodological comments. Novapex 2 (3): 69-91.

MERLE D. 2005. - The spiral cords of the Muricidae (Gastropoda, Neogastropoda): importance of ontogenetic and topological correspondences for delineating structural homologies. Lethaia 38: 367-379.

Merle D., Garrigues B. \& Pointier J. P. 2011. - Fossil and Recent Muricidae of the World - Part Muricinae. Conchbooks, Hackenheim, $648 \mathrm{p}$.

PETUCH E. J. 1994. - Atlas of Florida Fossil Shells (Pliocene and Pleistocene Marine Gastropoda). Chicago Spectrum Press, Evanston, Illinois: 1-394. 
Piton B. \& LAROCHE J. 1993. — Quelques caractéristiques hydroclimatiques du sud de Madagascar. Bulletin Océanographie et Pếches [La Réunion] 37: 46-54.

Spalding M. D., Fox H. E., Allen G. R., Davidson N., Ferdana Z. A., Finlayson M., Halpern B. S., Jorge M. A., Lombana A., Lourie S. A., Martin K. D., McManus E., Molnar J., ReCCHIA C. A. \& ROBERTSON J. 2007. - Marine ecoregions of the world: A bioregionalization of coastal and shelf areas. BioScience 57 (7): 573-583.

SHUTO T. 1969. - Neogene gastropods from Panay Island, the
Philippines. Memoirs of the Faculty of Science, Kyushu Imperial University. Series D, Geology 19(1): 1-250.

VILVENS C. 2014. - New species and new records of Calliostomatidae (Gastropoda: Trochoidea) from Madagascar. Novapex 15(HS 9): 1-29.

VOKES E. H. 1964. - Supraspecific groups in the subfamilies Muricinae \& Tritonaliinae (Gastropoda: Muricidae). Malacologia 2 (1): 1-41.

VOKES E. H. 1970. - Cenozoic Muricidae of the Western Atlantic region. V. Pterynotus and Poirieria. Tulane Studies in Geology and Paleontology 8 (1): 1-50.

Submitted on 23 January 2015; accepted on 6 May 2015

published on 25 September 2015. 